Portland State University

PDXScholar

1974

\title{
Survey of Parental Attitudes Towards Health Services in the Beaverton Schools
}

\author{
Nancy M. King \\ Portland State University \\ Lee B. Maxey \\ Portland State University \\ Nancy M. Stegen \\ Portland State University \\ Lesley D. Unthank \\ Portland State University
}

Follow this and additional works at: https://pdxscholar.library.pdx.edu/open_access_etds

Part of the Social Work Commons

Let us know how access to this document benefits you.

\section{Recommended Citation}

King, Nancy M.; Maxey, Lee B.; Stegen, Nancy M.; and Unthank, Lesley D., "Survey of Parental Attitudes Towards Health Services in the Beaverton Schools" (1974). Dissertations and Theses. Paper 1772. https://doi.org/10.15760/etd.1771

This Thesis is brought to you for free and open access. It has been accepted for inclusion in Dissertations and Theses by an authorized administrator of PDXScholar. Please contact us if we can make this document more accessible: pdxscholar@pdx.edu. 
SURVEY OF PARENTAL ATTITUDES TOWARDS HEALTH

SERVICES IN THE BEAVERTON SCHOOLS

\author{
by \\ NANCY N, KING \\ LEE B, MAXEY \\ NANCY M. STEGEN \\ LESLEY D. UNTHANK
}

A report submitted in partial fulfillment

of the requirements for the degree of

\author{
MASTER OF \\ SOCIAI WORK
}

\author{
Portland State University \\ 1974
}


TO THE OFFICE OF GRADUATE STUDIES \&

The members of the committee approve the group project of Nancy King, et al. presented June 3, 1974.

Nancy Woroloff, Chaitman

Dr! Quentin Clarkson

Dr. Wayng Neubureer 
TABLE OF CONTENTS

I. INTRODUCTION.........................

II. PROCEDURES AND DESIGN ....................

1. The Instrument................... 3

2. The sample.......................4

3. The Pilot.....................4

4. Training of Interviewers..............6 6

5. Data Collection....................6

III. ANALYSIS OF DATA..................... 8

1. Introduction....................8

2. Background Information............... 9

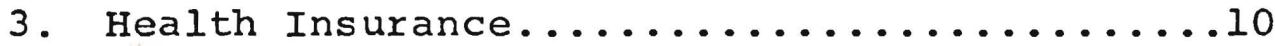

4. Medical Examinations.................12

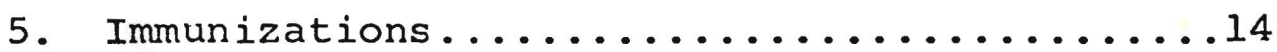

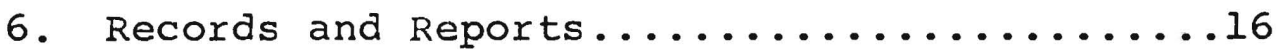

7. Screening and Referral Procedures..........19

8. First Aid and Emergency Care.................

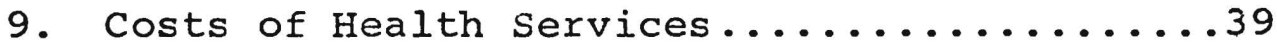

10. Comments and suggestions from Parents......41

IV. SUMMARY AND CONCLUSIONS ...................42

v. APPENDICES ............................ 45

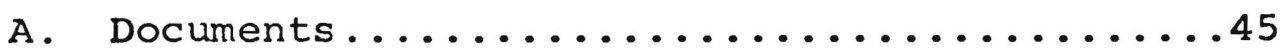

B. Analysis of Data..................60

C. Background Information...............61

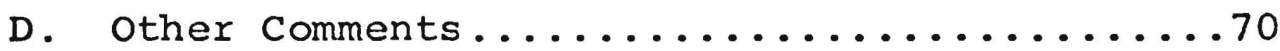




\section{INTRODUCTION}

There is a growing community concern about the development of preventative health and health maintenance programs. Recent changes in the state health regulations are beginning to show this concern. These contemporary changes bring about the need for the school district to evaluate the status of their existing programs in the light of the changing community requirements. The purpose of this study was, therefore, to collect and evaluate information on health services provided to children enrolled in the Beaverton School District. The primary areas of inquiry in the study were (1) parents attitudes concerning how existing programs have affected their children, (2) parents perceptions of needed and/or additional health services which could be provided by the school system, parents attitudes toward budgetary decisions concerning possible changes and improvements in health services.

The data collected and analyzed will be useful in making district decisions concerning projected or proposed health service changes and improvements within the school district.

The following areas were taken into consideration in reviewing parental attitudes toward health services:

1. Insurance - Do parents make use of the school accident insurance for their children?

2. Medical Examinations - Should a current physical examination be required by the school district for every first grade or transfer student?

3. Immunization law - How does the new Oregon Immunization law affect first grade and transfer students? What are the parents attitude toward the law? 
4. Reports and Records - What school records, including behavioral information, do the parents feel should be kept by the school?

5. Screening and Referrals - What are the parents attitudes toward the school's role in screening and referrals?

6. First aid and emergency care - What are the parents feelings about the school's role in first aid and emergency situations that involve their children at school?

7. Cost of Health Services - What are the parents' opinion of changes or improvements in the school health services and would they accept changes in the health services with or without additional cost?

Presently, all of the schools keep records on immunizations, names of family physicians, and days absent. Within the school district, the services of nurses are contracted through the Washington County Public Health Department. The present nursing schedule involves a biweekly or a monthly contact with the schools. This is done by either telephone or a school visit by the nurses.

The study of parental attitudes toward health services has been conducted by the Department of Administrative Services with the assistance of four Master of Social Work candidates who are submitting the study as partial fulfillment of requirements for this degree. 


\section{PROCEDURES AND DESIGN}

\section{The Instrument}

An interview schedule was used to collect data from a random sample of parents of school children in the Beaverton School District. The interview schedule was designed to consist of structured questions which could be answered by "yes" or "no" or with specific information. Some open-ended questions were included as well. While "yes" and "no" responses were desirable for purposes of tabulation and data presentation, it was felt that it was also necessary to be aware of the attitudes which could result in open-ended responses. Since parental attitudes were the focus of the study, comments and exceptions were included in the schedule to elicit qualifying data.

Personal interviews were held in the homes of the respondents. The advantages of using an interview schedule are many. The presence of the interviewer acts as a stimulus to elicit responses and he is readily available to explain the meaning of questions which may be unclear to the respondent. Additionally, the interview schedule is known to have a higher response rate than the telephone interview or the mailed questionnaire. Personal interviews were possible due to the relatively small size of the sample. 


\section{Sample}

The parents to be interviewed were randomly chosen from a list of the names of the children enrolled in the Beaverton School District. The sample was stratified by school level: elementary, intermediate, and high school. There are a total of 10,048 children enrolled at the elementary level, 5,399 at the intermediate level, and 4,603 at the high school level. The sample size from each strata was approximately proportionate to the number of students at each level.

A sample of 250 families was chosen: 125 from the elementary list, 64 from the intermediate list, and 64 from the high school list of students. Duplication of families was avoided so that no one family would be interviewed more than once. One or both parents were interviewed and counted as a single response.

The elementary sample was drawn as a two-stage sample from the 26 elementary schools. The parent sample was drawn from eight schools which were randomly sampled from the 26 schools.

A replacement sample drawn at the same time as the regular sample was used to replace those potential respondents who had moved outside the school district or who had moved within the school district but could not be located.

\section{$\underline{\text { Pilot }}$}

In January, 1974, the interview schedule was piloted on two elementary school families, two intermediate families, and two high school families. Generally, it was felt that 
the parents interviewed were extremely positive toward the interview. The pilot resulted in the re-wording of some questions to permit conversational flow and the reconstruction of some sets of questions. A copy of the revised interview schedule can be found in Appendix A. 
Training the Interviewers

Early in February, four interviewers employed by the school district met with the study group for a two-hour training session. The interviewers were given both verbal and written directions. (See Appendix A)

\section{Data Collection}

Interviewers called on the parents at home without a prearranged appointment and attempted to complete the interview at that time. To facilitate the interviewer's entrance into the respondent's homes, the coordinator of student services sent an introductory letter to the parents about one week before the interview was expected to take place. The letter explained the purpose of the study, gave notification of the impending interview, and requested their cooperation. (See Appendix A)

Data collection occurred from January to April, 1974. When the gas crisis reached its height in early March, a change in approach was instituted. Visiting the subjects' homes without a prearranged appointment frequently resulted in numerous return visits. This method became an impractical and expensive one during the gas shortage. Therefore, appointments were made by telephone. This method proved to be highly successful and was used for the remainder of the collection period, as only a few refusals were encountered.

\section{Follow-up on Move Aways and Refusals}

Anticipating that some of the sampled families might have 
moved and some might refuse to be interviewed, a system was constructed to deal with these events. It was decided that a refusal would be counted as a response and would not be replaced. An explanation of the conditions under which a response would be considered to be a refusal is included in Directions to Interviewer. (See Appendix A)

If the sampled family had moved outside the school district, it was replaced by a name from the replacement list for the appropriate school level. If the family had moved within the district, efforts were made to locate them so that the interview could be completed. When those efforts failed, a replacement was used. 
III. RESULTS

\section{Introduction}

From a total sample of 249 interviews, only 14 respondents refused to complete the interview.

Interview refusals and completions are described below according to the three school levels examined in the study (see Table

TABLE 1

Interview Returns Frequencies by School Level

\begin{tabular}{|c|c|c|c|c|}
\hline & Completed & Interviews & Refusals & Totals \\
\hline Elementary & & 116 & 7 & 123 \\
\hline Intermediate & & 60 & 4 & 64 \\
\hline High School & & 59 & 3 & 62 \\
\hline TOTALS & & 235 & 14 & 249 \\
\hline
\end{tabular}

A total sample of 235 was used for all analyses. Please see Appendix B for a discussion of the analyses of data. 


\section{Background Information}

Background information collected on each responding family included:

(1) elementary school zone as an indicator of geographic location;

(2) school level;

( 3) race;

(4) number of children in the school level represented;

(.5) the age of each child in that school level;

(6) the sex of each child;

(7) the grade level for each child;

(8) the school attended;

(9) the number of adults in the household;

(10) the number of children in the household;

(11) the number of parents for those children in the school level which the family represented;

(12) the occupations of the wage earners in the family; and

(13) the family's present yearly income.

The reason for collecting demographic information was to determine whether any of the items might be associated with specific parent attitudes toward health services in the schools. See Appendix $C$ for detailed results of background information. 


\section{Insurance}

Two questions were asked about insurance to determine the amount and extent of insurance coverage provided by parents.

The following question was asked to find out how many parents enroll their children in the school accident coverage offered through the school district:

"Is your child (children) covered by the school accident insurance?"

\section{TABLE 2}

Percentage of parents who enroll their children in the school accident insurance

\begin{tabular}{|c|c|c|c|}
\hline & Elementary & Intermediate & High School \\
\hline Yes & 30 & 31 & 40 \\
\hline No & 68 & 68 & 59 \\
\hline
\end{tabular}

Approximately one-third of the parents responded that their child (children) was covered by school health insurance.

The parents were also asked:

\footnotetext{
"Is your child (children) in elementary (junior high, high school) presently covered by health insurance?"

Most of the parents responded affirmatively to this question.
} 
TABLE 3

Percentage of parents who enroll their children in health insurance.

\begin{tabular}{|c|c|c|c|}
\hline & Elementary & Intermediate & High School \\
\hline Yes & 97 & 90 & 94 \\
\hline No & 2 & 10 & 5 \\
\hline
\end{tabular}


Medical Examinations

Parents were asked two questions designed to assess their attitude toward requiring medical examinations.

"Do you believe schools should require a child to have a medical exam when he or she enters the first grade?"

Most of the respondents felt that schools should require a medical exam for children entering the first grade.

TABLE 4

Percentage of parents who felt medical exams should be required for children entering the first grade

Elementary Intermediate High School

\begin{tabular}{lccc}
\hline \hline Yes & $\begin{array}{c}81 \\
\text { *(74-88) }\end{array}$ & $\begin{array}{c}88 \\
(77-95)\end{array}$ & $\begin{array}{c}93 \\
(83-98)\end{array}$ \\
\hline No & 17 & 10 & 6 \\
\hline NR & 0 & 10 & 6 \\
\hline
\end{tabular}

* Numbers in parenthesis are $95 \%$ confidence intervals See Appendix B.

Parents were given a chance to make additional comments about their answer to this question.

The most numerous comment given by respondents in all three levels suggest that exams should be provided for those parents who cannot afford the cost. For a complete list of additional comments see Appendix D. 
Parents were also asked the following question:

"Do you believe the schools in the

Beaverton School District should require

a medical examination from any student

entering from another school district?

About one-half of the parents responding felt examinations should be required as Table 5 indicates.

TABLE 5

Percentage of parents who feel medical examinations should be required for new students in the district

Elementary

Yes

42

*(33-52)

56

\section{No}

High School

Intermediate

40

47

(28-54)

(34-61)

55

52

Don't know

3

No Response 11

* $95 \%$ confidence intervals

Most of the parents that added comments felt that it was not necessary to require examinations, if the child had one on record from a previous school. For additional comments see Appendix D. 
Immunization

Because there had been a recent law passed in the Oregon Legislature pretaining to Immunizations, the parents were asked :

"Do you know about this law?"

TABLE 6

Percentage of parents having knowledge of new immunization law

Elementary Intermediate High School

\begin{tabular}{|c|c|c|c|}
\hline Yes & $\begin{array}{c}74 \\
*(64-82)\end{array}$ & $\begin{array}{c}68 \\
(55-80)\end{array}$ & $\begin{array}{c}61 \\
(41-73)\end{array}$ \\
\hline No & 25 & 30 & 35 \\
\hline
\end{tabular}

*95\% coñfïdence intervals

About two-thirds of the respondents knew about this law. As the table indicates more elementary parents were aware of the recent legistative decision than were the intermediate or high school parents.

"Is your child (children) a first grader or a transfer student?" If so, they would have been affected by the immunization law, so we would like to know what your attitude is toward this law."

Fifty-three parents or $23 \%$ of the total sample indicated that their children were first graders or transfer students. The majority of people who did comment stated that they supported the law. For a listing of additional comments see Appendix D. 
The parents were also asked the following question about immunization:

"To your knowledge are your child's immunizations current? (smallpox, diphtheria, whooping cough, tetanus, polio, measles, tuberculin)"

\section{TABLE 7}

Percentage of parents whose children

have current immunization. Elementary Intermediate High School

\begin{tabular}{lccc}
\hline $\begin{array}{l}\text { Yes } \\
\text { Immunization } \\
\text { is current }\end{array}$ & *(84-95) & $\begin{array}{c}88 \\
(77-95)\end{array}$ & $\begin{array}{c}84 \\
(73-93)\end{array}$ \\
\hline $\begin{array}{l}\text { No } \\
\begin{array}{l}\text { Immunization } \\
\text { is not current }\end{array}\end{array}$ & 6 & 8 & 6 \\
\hline Don't Know & 1 & 3 & 8 \\
& & & \\
\hline *95\% confidence intervals
\end{tabular}

*95\% confidence intervals

Most parents indicated that to their knowledge, their child's immunizations were current. It is interesting that the high school level parents were most likely to respond in the "don't know" category. For a list of comments see Appendix D. 


\section{Reports and Records}

The data in this section may be used to describe the extent to which parents believe the schools should keep records of specific medical and behavioral information. Table indicates responses to the following question about medical records:

"Should students' records and reports be kept for the following medical areas?"

TABLE 8

Responses Regarding Retention of Medical Data

\begin{tabular}{|c|c|c|c|}
\hline Medical Area & $\begin{array}{l}\text { \% } \\
\text { Elem. } \\
\text { Sample }\end{array}$ & $\begin{array}{c}\% \\
\text { Inter. } \\
\text { Sample }\end{array}$ & $\begin{array}{c}\text { High School } \\
\text { Sample }\end{array}$ \\
\hline Name of family physician & 96 & 98 & 96 \\
\hline Days absent & 87 & 95 & 86 \\
\hline Immunizations & 94 & 91 & 76 \\
\hline Physicians' recommendations & 85 & 91 & 91 \\
\hline $\begin{array}{l}\text { History of past and current } \\
\text { illnesses, accidents, and } \\
\text { disabilities }\end{array}$ & 81 & 88 & 81 \\
\hline School nurses' reports & 83 & 83 & 79 \\
\hline $\begin{array}{l}\text { Record of teacher referrals } \\
\text { or follow-ups }\end{array}$ & 78 & 76 & 74 \\
\hline Teachers' health observations & 67 & 76 & 67 \\
\hline Dentists' recommendations & 56 & 58 & 59 \\
\hline $\begin{array}{l}\text { Annual health summary by } \\
\text { teacher }\end{array}$ & 50 & 43 & 42 \\
\hline
\end{tabular}


"Name of family physician" received the highest percentage of "yes" responses on all school levels, while "annual health summary by the teacher" received the fewest "yes" responses on all school levels. Two other categnries which received an especially low percentage of "yes" responses were "dentists' recommendations" and "teachers' health observations." It seems fair to conclude that a substantial number of parents do not want records to be kept of health observations or summaries made by the teachers. It also seems fair to conclude that many parents do not think dentists' recommendations should be kept in school health records.

The only meaningful response difference among the three school levels was in answer to the question, "Should student records and reports be kept for immunizations?" Seventy-six percent of the high school sample answered "yes" while 91\% and $94 \%$ of the intermediate and elementary samples, respectively, answered "yes." Some of this difference may be due to the fact that most children have received all important immunizations by the time they reach high school.

This section of the interview schedule also asked whether records and reports should be kept for two kinds of behavioral information. Table 9 indicates the percentage of respondents who felt records should be kept for those areas. 
TABLE 9

Responses Regarding Retention of Behavioral Data

\begin{tabular}{|c|c|c|c|}
\hline Behavioral Areas & $\begin{array}{c}\% \\
\text { Elem } \\
\text { Sample }\end{array}$ & $\begin{array}{c}\% \\
\text { Inter. } \\
\text { Sample }\end{array}$ & $\begin{array}{c}\% \\
\text { High School } \\
\text { Sample }\end{array}$ \\
\hline $\begin{array}{l}\text { Teacher's observations } \\
\text { of classroom behavior }\end{array}$ & $\begin{array}{c}80 \\
(72-87) *\end{array}$ & $\begin{array}{c}70 \\
(57-81)\end{array}$ & $\begin{array}{c}74 \\
(6 z-85)\end{array}$ \\
\hline $\begin{array}{l}\text { Recommendations from } \\
\text { other professionals } \\
\text { (psychologists, social } \\
\text { workers, counselors, } \\
\text { public health nurses, } \\
\text { etc.) }\end{array}$ & $\begin{array}{c}82 \\
(75-89)\end{array}$ & $\begin{array}{c}83 \\
(71-92)\end{array}$ & $\begin{array}{c}81 \\
(69-90)\end{array}$ \\
\hline
\end{tabular}

For both areas a majority of the population favors keeping records of teachers' observations and professionals' recommendations concerning classroom behavior. 


\section{Screening and Referral Procedures}

In order to gain an understanding of parents' attitudes toward screening and referral in several areas parents were asked the following question:

"Do you feel that the schools should provide screening and referral services for children in the following areas:

The areas covered included vision, hearing, dental problems, weight and height, emotional or behavioral problems and handicapping conditions.

Vision and Hearing

An overwhelming number of parents at all three levels would like to see screening and referral procedures instituted by the schools for vision and hearing.

TABLE 10

Responses favoring screening and referral procedures for vision and hearing

\begin{tabular}{lccc} 
& $\%$ & $\%$ & $\%$ \\
& Elementary & Intermediate & High School \\
\hline Vision & 98 & 96 & 93 \\
& $*(94-100)$ & $(89-100)$ & $(84-98)$ \\
Hearing & 97 & 96 & 93 \\
& $*(93-99)$ & $(89-100)$ & $(84-98)$ \\
\hline
\end{tabular}

*95\% confidence intervals.

Almost all parents want their children enrolled in programs for vision and hearing screening and referral should such programs be instituted by the schools. 
TABLE 11

Responses of parents wishing own children enrolled in vision and hearing programs

at school

\begin{tabular}{lccc}
\hline & $\begin{array}{c}\% \\
\text { Elementary }\end{array}$ & Intermediate & High \\
& 99 & 100 & 100 \\
Vision & 99 & 100 & 100 \\
\hline
\end{tabular}

Emotional/Behavioral problems and Handicapping Conditions

A majority of parents at all three school levels support screening and referral programs for emotional/behavioral problems and handicapping conditions.

TABLE 12

Responses favoring screening and referral programs for emotional/behavioral problems and handicapping conditions

\begin{tabular}{|c|c|c|c|}
\hline & $\begin{array}{c}\% \\
\text { Elementary }\end{array}$ & $\begin{array}{c}\% \\
\text { Intermediate }\end{array}$ & High ${ }^{\%}$ School \\
\hline $\begin{array}{l}\text { Emotional/Behavioral } \\
\text { Problems }\end{array}$ & $\begin{array}{c}89 \\
*(83-94)\end{array}$ & $\begin{array}{c}85 \\
(73-93)\end{array}$ & $\begin{array}{c}88 \\
(77-95)\end{array}$ \\
\hline $\begin{array}{l}\text { Handicapping } \\
\text { Conditions }\end{array}$ & $\begin{array}{c}88 \\
*(81-93)\end{array}$ & $\begin{array}{c}86 \\
(75-94\end{array}$ & $\begin{array}{c}84 \\
(73-93)\end{array}$ \\
\hline
\end{tabular}

$95 \%$ confidence intervals

Almost all parents wanted their children enrolled in such programs should the school implement them. 
TABLE 13

Responses of parents wishing own children enrolled in emotionai/behavioral and handicap. screening programs at school

\begin{tabular}{lccc}
\hline \hline & $\begin{array}{c}\% \\
\text { Elementary }\end{array}$ & $\begin{array}{c}\% \\
\text { Intermediate }\end{array}$ & High \\
\hline $\begin{array}{c}\text { Emotional/Behavioral } \\
\text { Problems }\end{array}$ & 97 & 96 & 100 \\
$\begin{array}{l}\text { Handicapping } \\
\text { Conditions }\end{array}$ & 97 & 100 & 98 \\
\hline
\end{tabular}

Dental Problems and Height/Weight Determinations

Parents at all levels were least interested in having screening and referral programs instituted in the schools for these two problem areas. However, in comparison to the programs asked about, a majority of parents at all levels do support screening and referral for dental problems and weight/height determinations in the schools.

TABLE 14

Responses favoring screening and referral procedures for dental and height/weight problems

\begin{tabular}{lccc}
\hline \hline & $\%$ & $\%$ & $\%$ \\
& Elementary & Intermediate & High School \\
\hline Dental Problems & 65 & 55 & 72 \\
& $*(56-74)$ & $(42-68)$ & $(60-84)$ \\
Height/Weight & & & \\
Determinations & 53 & 51 & 54 \\
& $*(44-63)$ & $(38-65)$ & $(41-67)$ \\
\hline
\end{tabular}

Almost all respondents want their children enrolled in screening and referral programs for both dental problems and height/weight determinations should the schools institute such programs. 
TABLE 15

Responses of parents wishing own children enrolled in dental and height/weight programs at school

\begin{tabular}{|c|c|c|c|}
\hline & $\begin{array}{c}\% \\
\text { Elementary }\end{array}$ & $\begin{array}{c}\% \\
\text { Intermediate }\end{array}$ & High ${ }^{\%}$ School \\
\hline Dental Problems & 97 & 96 & 100 \\
\hline $\begin{array}{l}\text { Height/Weight } \\
\text { Determinations }\end{array}$ & 97 & 98 & 100 \\
\hline
\end{tabular}

Comments regarding screening and referral services

The comments are reported fully in Appendix D. Specific response categories were not frequent enough in any areas to be reported here except for 1) "screening and referral should be done by qualified professionals, and 2) screening and referral should be done only when a severe or obvious problem is present." 
TABLE 16

Most frequent comments on screening and Referral Procedures

(Number of Responses)

Elementary Intermediate High School

Screening and referral should be done by qualified professionals

\begin{tabular}{llll} 
Vision & 6 & 0 & 2 \\
\hline Hearing & 5 & 0 & 0 \\
\hline Dental & 4 & 0 & 0 \\
\hline Ht/Wt. & 1 & 0 & 0 \\
\hline $\begin{array}{l}\text { Emotional/ } \\
\text { Behavioral }\end{array}$ & 6 & 1 & 1 \\
$\begin{array}{l}\text { Handicapping } \\
\text { Conditions }\end{array}$ & 4 & 0 & 0 \\
\hline
\end{tabular}

\begin{tabular}{|c|c|c|c|c|}
\hline & Totals & 26 & 1 & $\underline{3}$ \\
\hline Screening and & Vision & 0 & 1 & 0 \\
\hline Referral should & Hearing & 0 & 2 & $\underline{0}$ \\
\hline be done only & Dental & 1 & 2 & 1 \\
\hline when "obvious" & Ht./Wt. & 3 & 2 & 1 \\
\hline or "severe" & Emotional/ & & & \\
\hline problem is & Behavioral & 1 & 2 & 1 \\
\hline \multirow[t]{3}{*}{ present } & Handicapping & & & \\
\hline & Conditions & 1 & 1 & 1 \\
\hline & Totals & 6 & 10 & 4 \\
\hline
\end{tabular}

A large majority of respondents chose not to comment on screening and referral services. However, in the areas most frequently mentioned by those whodid comment, elementary respondents seem to be more concerned than intermediate and high school respondents that these services be performed by qualified professionals.

In order to measure parents' satisfaction with the schools current screening and referral procedure, parents were asked:

"Has the school ever informed you that your child had (has) a problem in any of the areas above or in other areas?" 
Fifty-six percent of elementary parents reported school detection and referral of problems in various health areas. Conversely only $23 \%$ of intermediate parents and $29 \%$ of high school parents reported referral for such problems.

\section{TABLE 17}

Number of parents reporting school referrals for specific problem areas

\begin{tabular}{lccc}
\hline & Elementary & Intermediate & High School \\
\hline Vision & 22 & 5 & 5 \\
Hearing & 11 & 1 & 2 \\
Dental & 4 & 0 & 0 \\
Emotional/ & 14 & 6 & 5 \\
Behavior & & & 0 \\
Handicapping & 0 & 0 & \\
Conditions & & & 0 \\
Learning & 0 & 0 & 1 \\
Disabilities & 5 & 0 & 4 \\
Speech Problems & 9 & 2 & \\
Other & & & \\
& & & \\
\hline
\end{tabular}

At the elementary, intermediate, and high school levels vision and emotional/behavior problems are the greatest referral sources. Interestingly, vision reduces by about half at the intermediate and high school levels as a referral source. This is consistent with the data above for parents reporting school referrals for problems. Although referrals for visual problems decrease from elementary to secondary school levels, emotional/behavioral problems are not substantially reduced. 
Parents who responded were then asked to indicate the school's course of action after detection of the child's problem.

TABLE 18

School Referral Action after Detection of Child's Problem

* (Number of Responses)

Elementary Intermediate High School

Notified parent of

34

8

9

Initiated parent/

Teacher or Parent/

Child/Teacher

Conference

12

4

2

Provided Special

Services for

Child

12

0

1

Made Accurate

Referral or

recommendation

to Parents

17

2

1

Made Inaccurate

referral or

threatened to

suspend the child

0

2

2

Other

2

0

1

Notified Agency

or individual

other than parent

*Percentages are not used as some parents gave multiple responses to this question. 
Parents were also asked to indicate whether or not they were satisfied with the school's course of action.

TABLE 19

Parent feelings of satisfaction with school's response to child's detected problem(s)

\begin{tabular}{lccc}
\hline \hline & *(Number of Responses) & \\
& Elementary & Intermediate & High School \\
\hline & 56 & 10 & 12 \\
Satisfied & 9 & 4 & 5 \\
Dissatisfied & & & \\
\hline
\end{tabular}

Parents were next asked to suggest what the school's most appropriate referral action could have been after detecting the child's problem.

TABLE 20

Parent suggestions of most appropriate response to child's problem by school

\begin{tabular}{lccc}
\hline & $\begin{array}{l}\text { *(Number of Responses) } \\
\text { Elementary }\end{array}$ & Intermediate & High School \\
\hline $\begin{array}{l}\text { School's Actions } \\
\text { Were Appropriate }\end{array}$ & 50 & 7 & 10 \\
$\begin{array}{l}\text { School Should have } \\
\text { done More or Less or } \\
\text { should have detected } \\
\text { problem earlier }\end{array}$ & 11 & 7 & 6 \\
other & 4 & 0 & 1 \\
\hline
\end{tabular}

The majority of those parents at the elementary level who have experienced school referrals after detection of their child's problem are satisfied with the school's actions. A majority of the intermediate and high school parents were also satisfied with the school's actions. 
Parents were also asked to indicate problem areas which they felt "should have been reported by the school" but were not referred to the parents by the school. Response to this question was negligible, indicating that parents have probably been notified consistently when the school has detected problems with a child. (See Appendix D for specific comments by parents).

Parents were then asked to respond to the question:

"Do you think that the school should keep a record of the screening and referral processes for each child?"

And

"Should records be kept by the school of what happens to the child after he is referred by the school?"

TABLE 21

Maintenance of school records on screening and referral procedures and referral follow-up.

\begin{tabular}{|c|c|c|c|}
\hline & $\begin{array}{c}\% \\
\text { Elementary }\end{array}$ & $\begin{array}{c}\% \\
\text { Intermediate }\end{array}$ & High ${ }^{\%}$ school \\
\hline $\begin{array}{l}\text { School should keep } \\
\text { screening and } \\
\text { referral records on } \\
\text { each child }\end{array}$ & $\begin{array}{c}77 \\
*(69-85)\end{array}$ & $\begin{array}{c}78 \\
(66-88)\end{array}$ & $\begin{array}{c}86 \\
(75-94)\end{array}$ \\
\hline $\begin{array}{l}\text { School should keep } \\
\text { records of what happens } \\
\text { to child after referral } \\
\text { by school }\end{array}$ & $1 *(75-89)$ & $\begin{array}{c}68 \\
(55-80)\end{array}$ & $\begin{array}{c}71 \\
(58-82)\end{array}$ \\
\hline
\end{tabular}

*95\% confidence intervals 
A substantial majority of all parents believe that records should be kept in these areas. Elementary parents indicated a stronger interest in seeing records kept of what happens to the child during the post-referral process.

Parents were also asked to comment regarding the keeping of school records on screening and referral procedures and on what happens to the child after referral. Only a small portion of all parents in the total sample added additional comments on keeping records of what happens after referral. Scattering and low response levels made results negligible for this question. (see Appendix D for parents' comments). More comments were received from parents on recording of screening and referral procedures. $12 \%$ of elementary, $8 \%$ of intermediate and $7 \%$ of high school parents indicated that records should be kept "only when a problem is detected" by the schools. 9\% of the elementary, $5 \%$ of intermediate and $19 \%$ of high school parents responded in other scattered categories (See Appendix D for parents' comments).

In order to assess the parents feelings regarding the school's role in the referral and follow-up process, the parents were asked the following question:

"Should the school follow-up on referrals made to parents to determine what has been done for the child?" 
TABLE 22

School's Role in the Referral Process

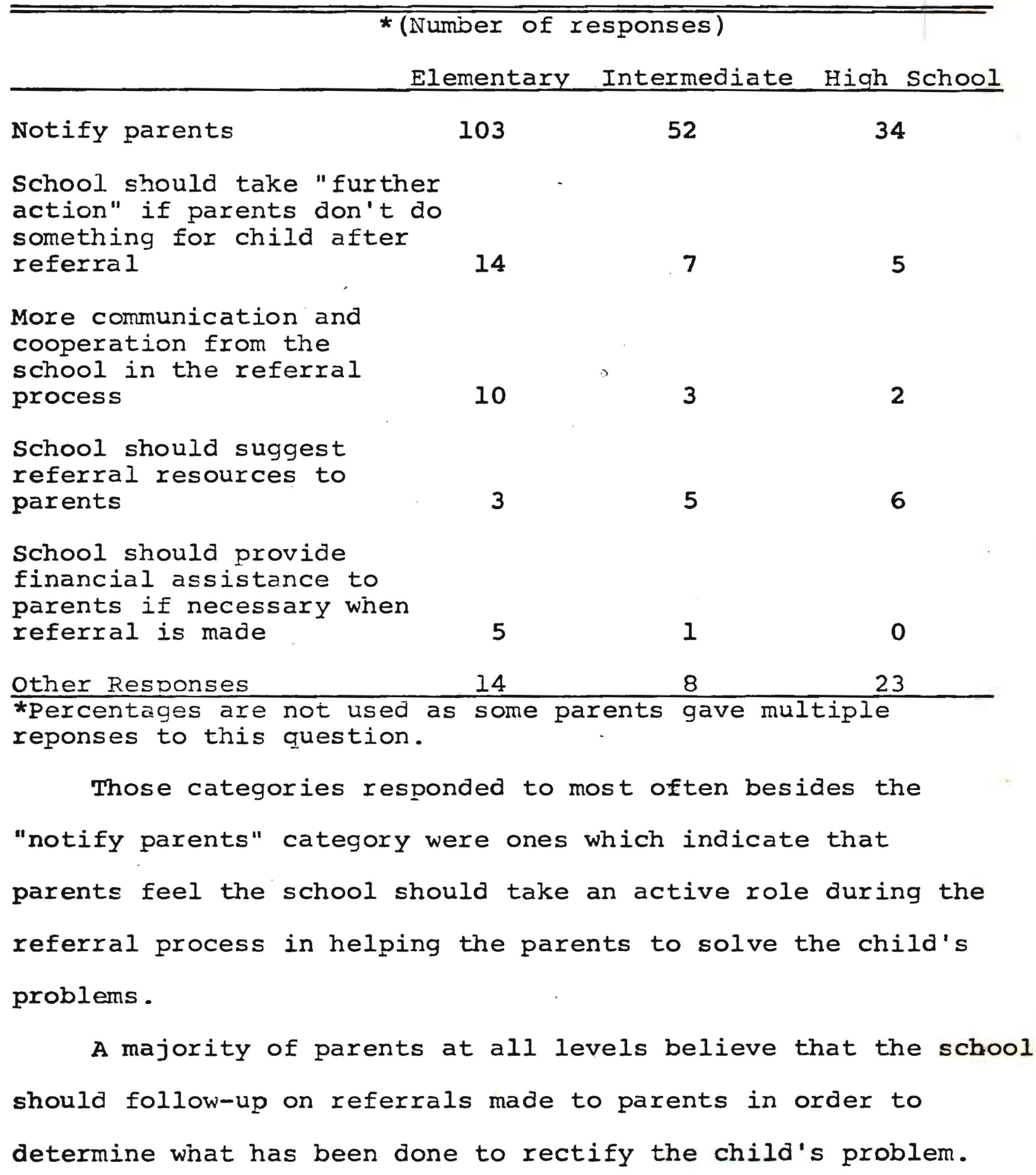


TABLE 23

Responses supporting school follow-up on referrals to parents

Elementary Intermediate High School

Schools should

follow-up on referrals to determine what has been done for the child *95\% confidence intervaIs 86 70 74 $*(79-92)$ $(57-81)$ $(62-85)$

parents were asked for their comments regarding school follow-ups on referrals.

TABLE 24

parent comments regarding school follow-ups on referrals to determine what has been done for the child

\begin{tabular}{|c|c|c|c|}
\hline & Elementary & Intermediate & High School \\
\hline $\begin{array}{l}\text { Follow-up only if } \\
\text { childs condition } \\
\text { doesn't improve or } \\
\text { parents don't } \\
\text { respond }\end{array}$ & 10 & 15 & 11 \\
\hline $\begin{array}{l}\text { Follow-up only if } \\
\text { child's problem is } \\
\text { serious, interferes } \\
\text { with his learning, or } \\
\text { is harmful to self } \\
\text { or others }\end{array}$ & 4 & 8 & 2 \\
\hline $\begin{array}{l}\text { Don't follow-up--This } \\
\text { is parents responsibility } \\
\text { after referral is made }\end{array}$ & 3 & 0 & 0 \\
\hline Other responses & 12 & 3 & 24 \\
\hline
\end{tabular}


Of those who did comment on the question, most feel that follow-ups are necessary only if nothing is done to rectify the child's problem or if the problem is serious enough to interfere with the child's functioning. Very few of the parents who commented were against school follow-ups on referrals. Of interest is the large number of high school parents who gave scattered responses. 


\section{Emergency and First Aid Care}

To assess parents attitude toward the kind of action the school should take in case a child is injured at school, the following questions were asked:

"In case your child requires minor first aid care the school should:"

1. Provide attention

2. Notify parents

3. Other

"In the case of emergency requiring more than minor first aid attention, the school should:"

1. Provide first aid attention

2. Notify parents

3. Notify family physician

An overwhelming majority of parents at all school levels prefer that the schools administer first aid to children for minor injuries and illness, and a substantial majority of parents want the school to administer first aid to children for major emergency situations. 
TABLE 25

Responses to administration of first aid by the school to children for illness or injury

Elementary Intermediate High School

Percentage of parents wishing minor first aid care to be administered by school

98 95 100

Percentage of parents wishing major first aid care to be administered by school 84 81 83

Although every parent in the sample wants the school district to notify the parents of any emergency situation requiring major first aid care, only a slight majority of parents want to be notified by the school when their child requires minor first aid care for illness or injury at school.

TABLE 26

Parents wishing school to notify parent when minor or major first aid care is required

Percentage of parents wishing to be notified when minor first aid administered to child

Percentage of parents wishing to be notified when major first aid administered to child 
$73 \%$ of elementary parents, $80 \%$ of the intermediate parents and $76 \%$ of high school parents want the schools to notify the family physician in emergency situations requiring that major first aid care be administered to the child. In the case of minor first aid care, few parents were interested in having the schools notify family doctors of the child's illness or injury (see Appendix D) .

Parents were also asked for general comments they wished to add to the questions regarding minor and major first aid care. Whereas negligible interest was shown in minor first aid situations, a good deal of interest was shown in how major first aid situations should be handled by the school. Many parents at all school levels indicated that the school should "notify a friend, relative or neighbor" or "call an ambulance, send the child to the hospital or do whatever is necessary to help the child" when major first aid care is required. For minor first aid situations, response was absent or negligible in these areas.

Parents were further asked to respond to:

"What happened the last time your child was ill or injured at school?" 
Approximately $1 / 3$ of all parents at each school level had had no ill or injured children in the Beaverton Schools, but about $2 / 3$ of parents at all levels had some interaction with the schools as a result of the illness or injury of their child at school.

\section{TABLE 27}

Parents who actually experienced

school action due to childs illness

or injury at school

\begin{tabular}{ccc}
\hline$\%$ & $\%$ & $\%$ \\
Elementary & Intermediate High \\
\hline
\end{tabular}

Parents reporting

illness or injury

of child at school

68

65

67

Parents were then asked if they felt that the school

had handled the situation well.

TABLE 28

Response to school handling of

illness or injury of child at school

Elementary Intermediate High School

Percentage of parents

feeling school's

actions_were appropriate

to the situation

59

53

55

Percentage of parents

feeling school's actions

were not appropriate

or who were unsure of

school's actions

9

12

12

When considering only those parents who have actually experienced school action regarding illness or injury to their child, the majority at all levels were satisfied with the school's handling of the situation. 
TABLE 29

Percentage of parents satisfied with school's handling of child's illness or injury at school

Elementary Intermediate High School

Percentage of parents actually experiencing school action who were satisfied with schools response to childs illness or injury

Percentage of parents actually experiencing school action who were unsure of or dissatisfied with school's response to child's illness or injury 13 18 18 *Figures in this table represent only precentages of those parents who have actually reported experiencing illness or injury of a child at school.

To assess parents feelings about the hiring of trained health care personnel in the schools, two questions were asked:

"Do you think it is necessary to make full time professional nursing services available to all students?"

"Do you think it is necessary to make full time trained health aides available instead of professional nurses to all students?"

Parents in substantial numbers at all three school levels are opposed to the hiring of nurses in the schools. Responses were more varied as to whether or not trained health aides should be hired by the schools. 
TABLE 30

Responses regarding the hiring of trained health aides or nurses to administer first aid care in the schools.

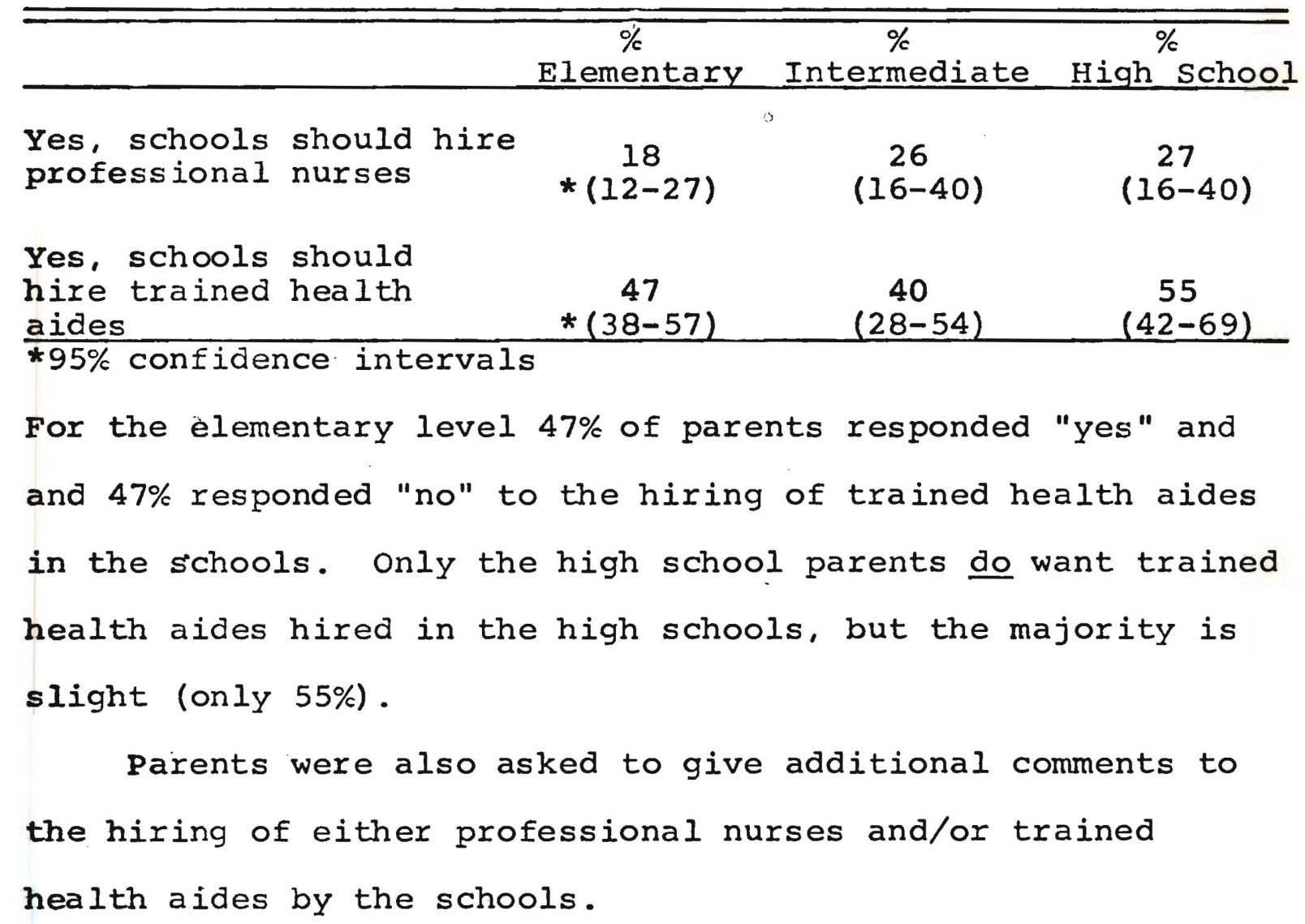


TABLE 31

Precentage of parent's comments on school hiring of professional nurses and trained health aides

Elementary Intermediate High School

No response to question

Use school personnel trained in first aid instead

Should hire nurses

Should hire health aides

Should have "qualified medical attention" available in schools

Current system

adequate

other responses
34

22

2

11

7

12

12
37

34

12

12

$8 \quad 10$

4

0

$13 \quad 1$

9

The most frequent responses at the elementary and intermediate levels indicate that parents are comfortable with "school personnel trained in first aid" available in the schools to handle emergencies or are "satisfied with the current system" (which generally amounts to having school staff trained in first aid available for emergencies).

At the high school level this trend reverses, with the most frequent responses indicating that those parents who commented want the schools to hire trained health aides or nurses. Also of note at the high school level is the high percentage of "other" responses. 


\section{Costs of Health Services}

Parents were asked to respond to two questions dealing with the cost of health services. The first was:

"If these services could be made available without additional expense, would you be in favor of their addition?"

TABLE 32

Percentage of parents wanting additional health services if no additional cost is necessary

\footnotetext{
Elementary Intermediate High School

Yes

*(89-98)

83

$(72-92)$

84

No

5

16

15

*95\% confidence interval.

Most parents were in favor of additional health services if no additional cost was involved. Although most of the sample didn't offer additional comments, a few interesting attitudes were expressed. Many respondents indicated that they would be in favor of additional health services---except for nursing services. Others indicated their desire for student volunteers. Some felt the district should spend money on "more important things"---even though it had been indicated that no additional cost would be necessary. For a complete list of the additional comments see Appendix D. The second question asked was:

"If it were not possible to add these services without some additional cost--would you still favor the addition of these services?"
} 
TABLE 33

Percentage of parents wanting additional health services if additional costs are necessary

Elementary Intermediate High School

Yes

72

*(63-80)

No

No response

26
55

$(42-68)$

43

1
69

$(69-49)$

30

*95\% confidence intervals.

Relatively fewer respondents favored additional health services if additional cost was involved. However, elementary level respondents were more in favor of adding health services when extra cost was involved than respondents at the other levels. In no case was there less than 55\% who were willing to pay extra for additional health services.

Most respondents didn't offer additional comments to this question. However, 29 qualified their answers by saying that "it depends on the cost." Other comments included statements confirming the adequacy of the current system, stipulations that the money must be used specifically for health services, and some stated that they wouldn't favor the addition of nurses and health aides. (For a:complete list of the additional comments see Appendix D). 


\section{Comments and suggestions from parents}

Parents were asked to respond to this final question: "Are there any other comments about Health Services in the schools that you'd like to make?"

The comment receiving the greatest number of responses (53) was "Satisfied with health services". The elementary sample gave 22 responses in this area with 17 at the intermediate level and 14 at the high school level. Nineteen comments related to health education in the areas of sex, personal hygiene, family life, drug education, or V.D. prevention were made. Thirteen parents commented that "parents should be notified when a child is in need of medical treatment and informed of results of medical tests administered". It is interesting to note that while 8 parents responded that "A better qualified person than a teacher is necessary for health observations, referrals and treatment", 6 said that "Teachers should be required to be familiar with health services and records and be trained to make referrals". Nine parents stated the "School should have access to a psychologist, social worker, and medical advisor." Other comments stressed the importance of health services, annual hearing and vision screening, routine followup, etc. For a complete listing of comments, see Appendix D. 


\section{SUMMARY AND CONCLUSIONS}

\section{Summary}

An attitude survey was conducted to determine parents' attitudes toward: (1) the adequacy of health services currently provided by the Beaverton school District, and (2) health services which the district might add to its current health program. A random sample of 249 families stratified by school level was selected. An interview schedule was then administered to the 235 families who agreed to participate.

\section{Conclusions}

Background Material: The total sample proved to be very homogeneous in family composition and background. No comparisons were made between background variables and parental attitudes since variation in response on background items was minimal.

Insurance: Slightly less than $33 \%$ of the respondents reported coverage under the school accident insurance. However, more than $90 \%$ indicated their children are covered by some type of health insurance.

Medical Exams: While more than $80 \%$ of the respondents feel medical exams should be required for first-grade children, only about $45 \%$ feel exams should be required for students transferring into the Beaverton School District.

Immunizations: Approximately $70 \%$ of the respondents stated they were aware of the immunization law. The percentage 
was slightly higher for parents of elementary children than for parents of older children. Of the total sample, $23 \%$ reported having children who were first-graders or transfer students. This group was consequently affected by the immunization law. The majority of those who commented indicated support for the law.

About $88 \%$ of the total respondents reported that their child's immunizations were current.

Records and Reports: Responses indicate that over 75\% of the total sample believe records and reports should be kept for seven of the ten medical areas. Approximately 50\% of the respondents feel records and reports should be kept for the remaining three medical areas.

More than $75 \%$ of the respondents believe records should be kept for the two behavioral areas.

Screening and Referral: A large majority (more than 95\%) of the sample favor screening and referral in the schools for vision and hearing problems. Eighty-five percent favor screening and referral for behavioral/emotional and handicapping problems. Fewer (about 50\%) want screening and referral for height/weight and dental problems.

Roughly $50 \%$ of all elementary, $25 \%$ of all intermediate, and $25 \%$ of all high school parents reported having experienced a referral from the schools. The majority of those were satisfied with the school's action.

Most parents interviewed feel the schools should keep records of referrals and should follow-up on referrals to 
determine what was done for the child.

Emergency and First Aid Care: The majority of parents want the schools to administer both minor and major first aid care. Specifically, 95\% favor the administration of minor first aid and $80 \%$ favor the administration of major first aid.

All parents want to be notified of major first aid, while $60 \%$ want to be notified of minor first aid care.

About $65 \%$ of the parents stated their child had been ill or injured at school. Of those parents, more than $82 \%$ were satisfied with the school's action.

In response to questions about nursing services, about $25 \%$ of the total sample indicated the schools should hire full-time nurses and about 50\% indicated full-time trained health aides should be hired instead of nurses.

Cost of Health Services: Most parents (about 85\%) favor the addition and/or expansion of school health services if there were no additional cost. A majority (at least 55\%) favor the addition and/or expansion of services even if there were additional cost involved. 
Interviewer

Interview number

Time of contact: Date

Time

Date

Time

Date

Time

Date

Time

Elementary School Zone

Race: White other

School Level: Elementary

Junior $\mathrm{High}$

High School 


\section{BACKGROUND}

1. How many children do you have in elementary (junior high, high) school? (circle one school level)

2. For those children, complete the following information (starting with the oldest and proceeding to the youngest):

3. In your household, how many adults are there?

How many children?

How many parents?

(Count only parents of the children listed above.)

4. What are the occupations of the wage earners in your family? 


\section{MEDICAL EXAMINATIONS}

8. Do you believe schools should require a child to have a medical examination when he or she enters the first grade:

\section{$<$}

Yes
Yes, with exceptions
Exceptions :

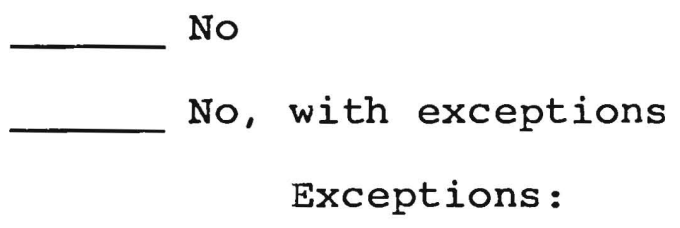

9. Do you believe the schools in the Beaverton School District should require a medical examination from any student entering from another school district?

Yes

Yes, with exceptions

Exceptions :

No

No, with exceptions

Exceptions : 


\section{IMMUNIZATIONS}

10. Schools are required by oregon Law to maintain a certain number of requirements and records concerning immunization, communicable disease and the health of children enrolled in the Oregon school districts.

1. Do you know about this law?

Yes__ No

2. Is your child (children) a first grader or a transfer student? Yes___ No If so, they would have been affected by the immunization law, so we would like to know what your attitude is toward this law.

Comments :

3. To your knowledge are your child's immunizations current? (smallpox, diphtheria, whooping cough, tetanus, polio, measles, tuberculin)

Yes__ No_ Don't know 
REPORTS AND RECORDS

11. The following are categories of information which are considered to be confidential and can be released to an outside agency only with the parent's permission. Should student records and reports be kept for the following medical areas?

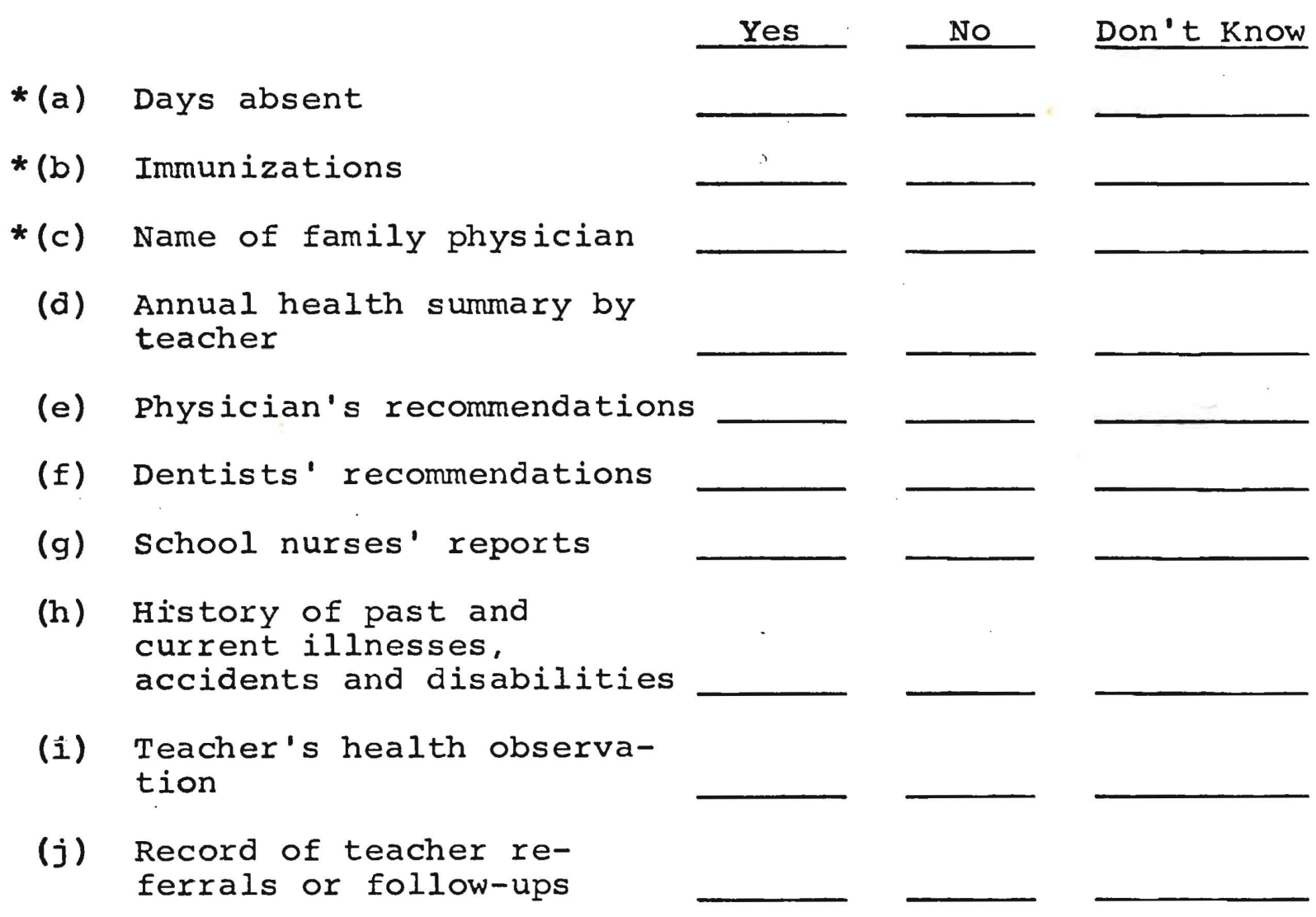

(*already kept)

The next two categories of behavioral information are released to certified school staff only when they prove a need to see them.

(k) Teacher's observations of classroom behavior

(1) Recommendations from other professionals (Psychologists, social workers, counselors, public health nurses, etc.) 


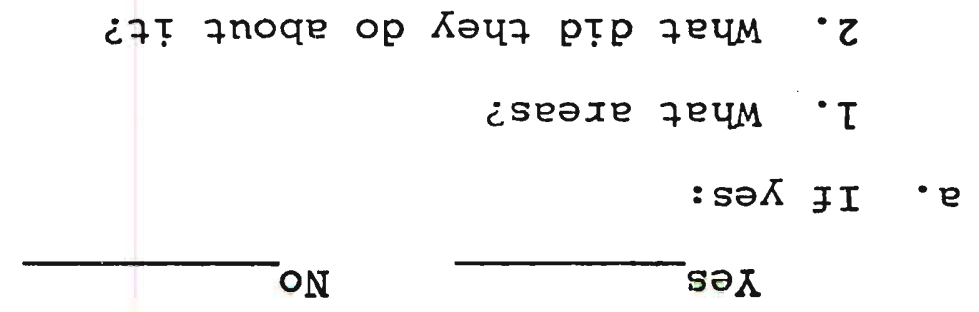

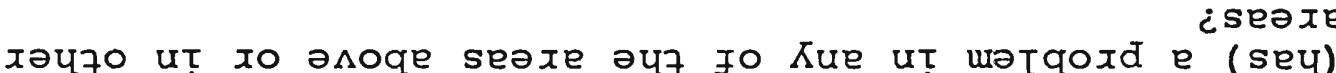

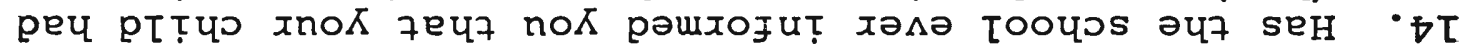

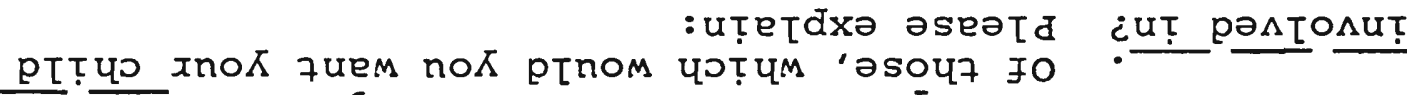

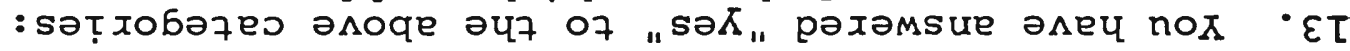

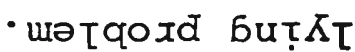

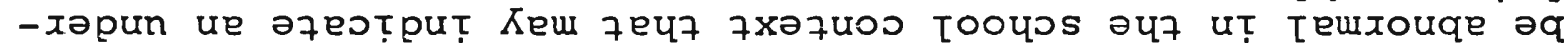

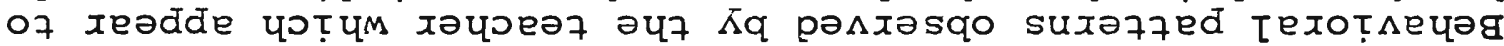

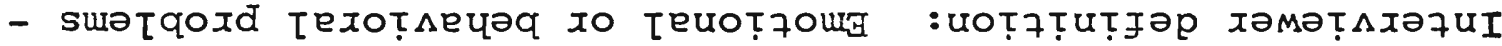

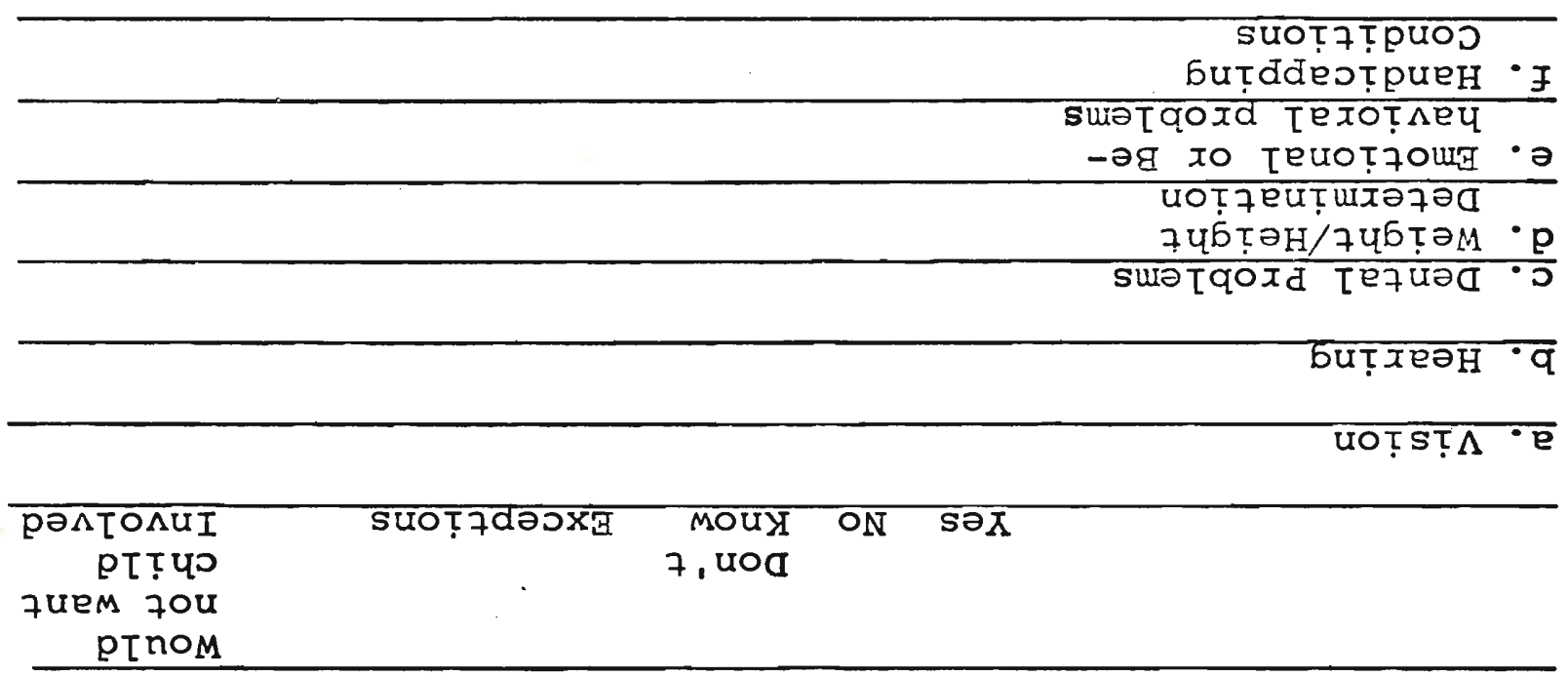

: seote

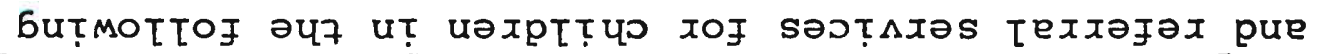

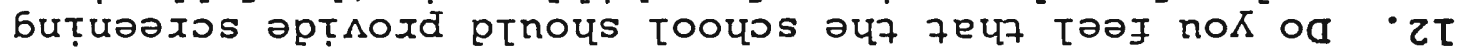

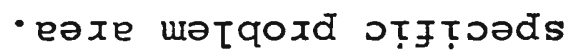

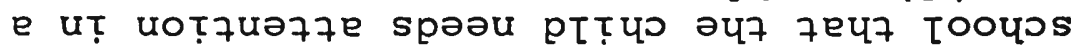

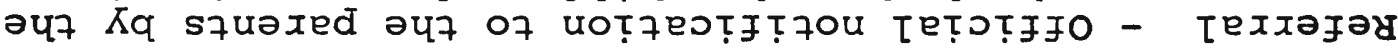

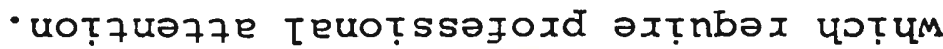

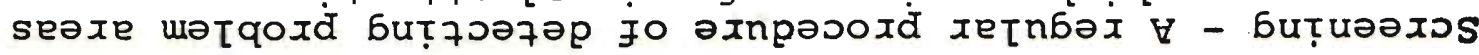

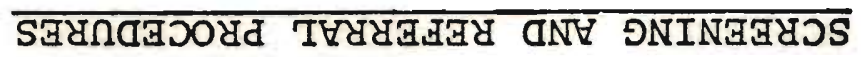




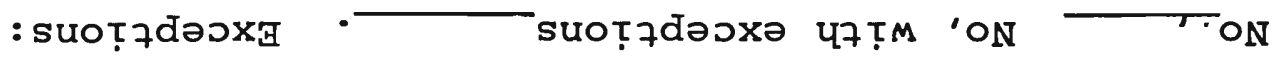

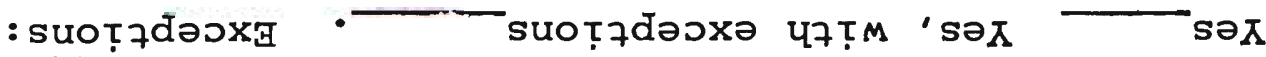

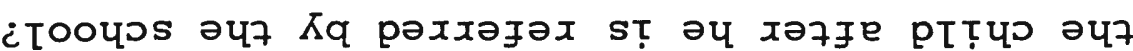

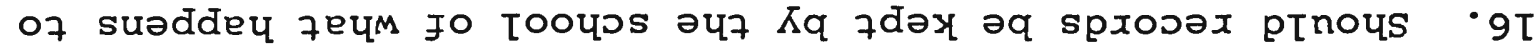

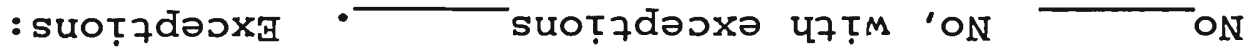

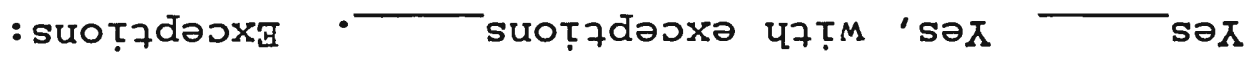

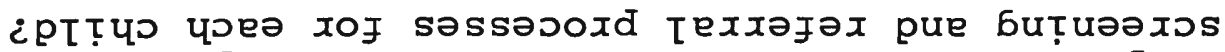

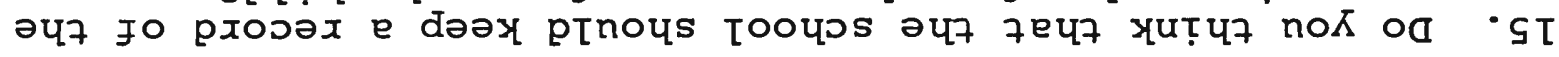

¿ssəooxd texiə⿱

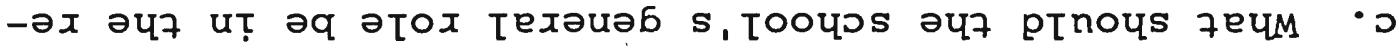

¿ (uәтqоxd әлоqе әч7 бuт̣pxебәx) иoт̣uт̣do

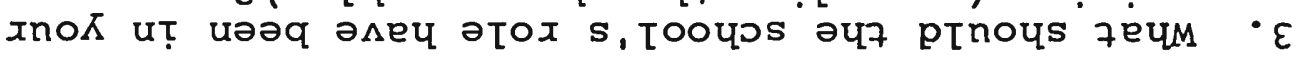

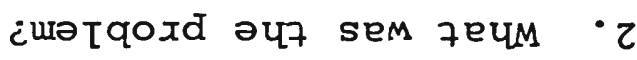

$\longrightarrow$ oN ${ }_{\text {səX }}$

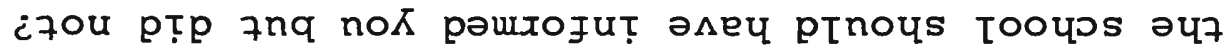

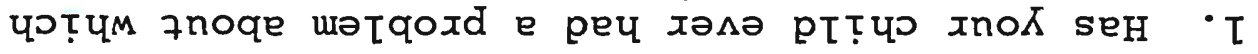

:OU II $\cdot q$

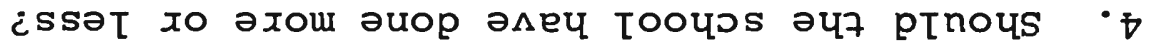

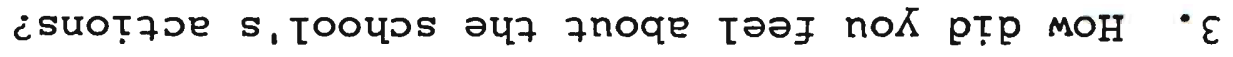




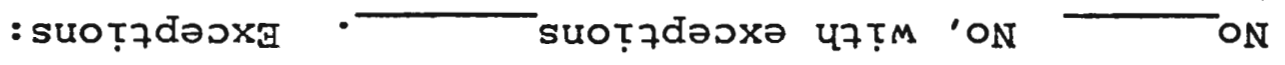

: suoțdəox日 
: s7uəunuos

ON

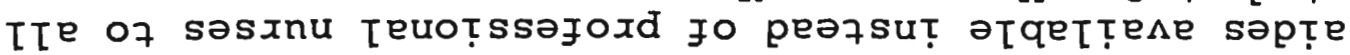

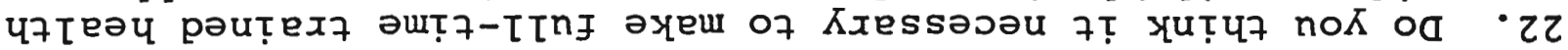

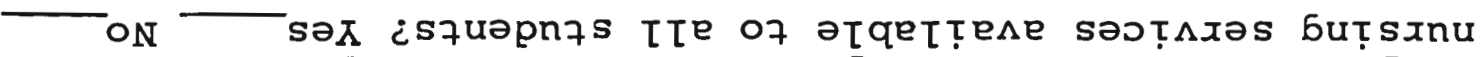

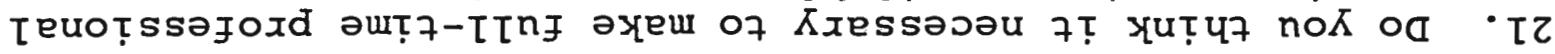

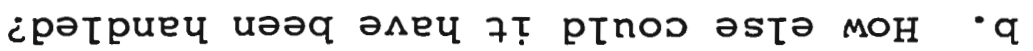

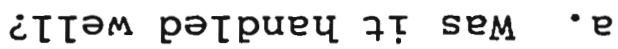

¿Tooyos 7 e pəxn!

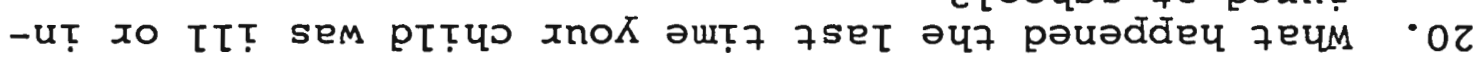

:s7uəuruos

¿op

тоOчอs әч7 pโnoys 7ечм 'pәчреәx

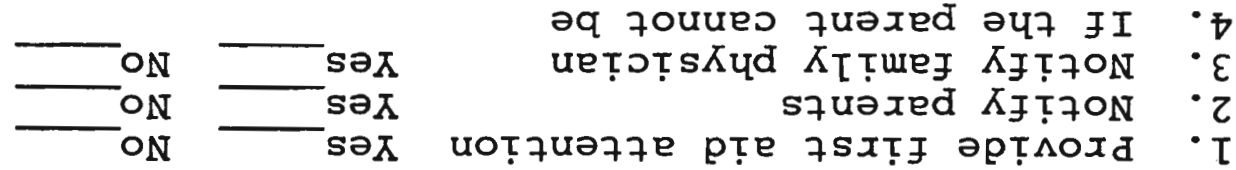

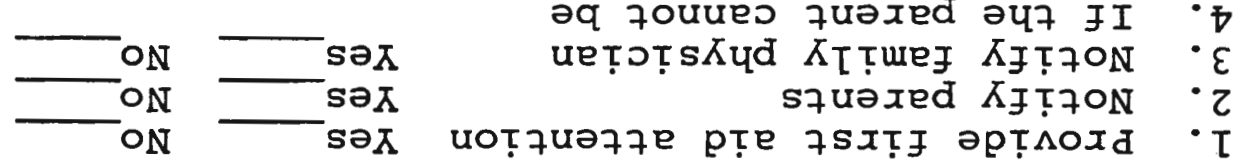

pInoys tooyss әч7 'uoț7uə77e pṭe

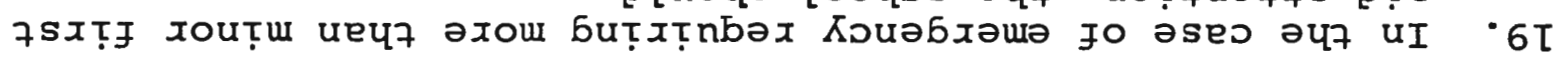

: squəururos

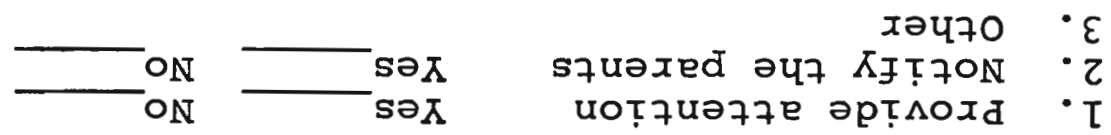

-- prnoys tooyss

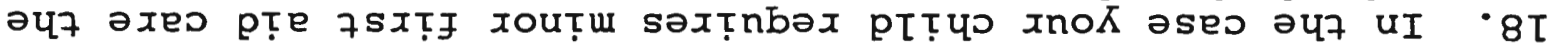

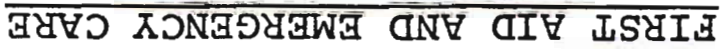

$\nabla S$ 
¿әxеu of әxтT ptnom noK 7ey7 stooyss

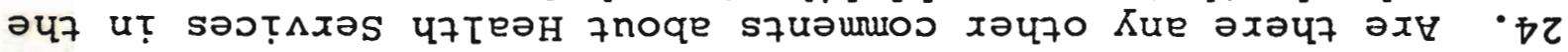

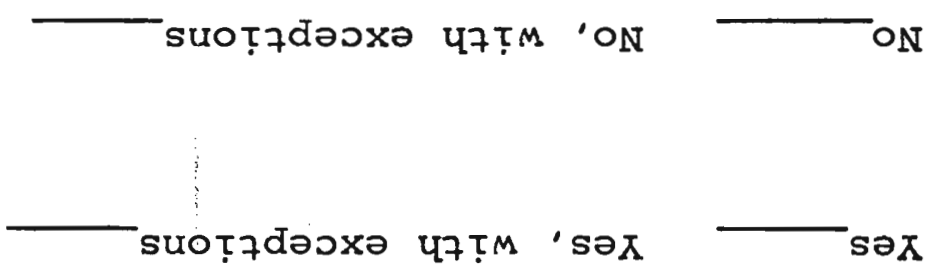

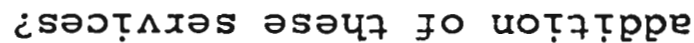

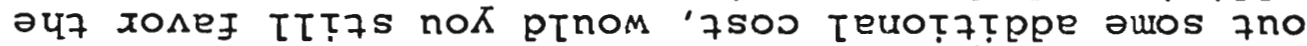

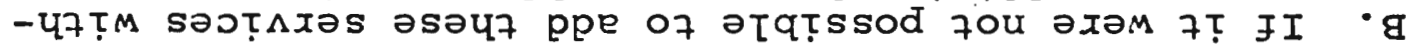

Uoț7dəoxə 47ṬM 'ON

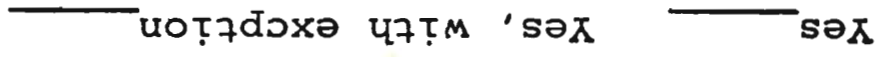

¿uoțтฺpe

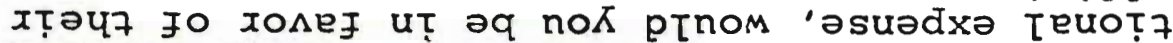

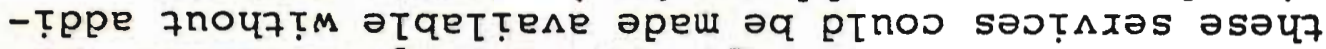

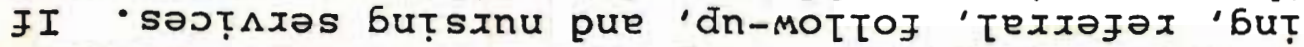

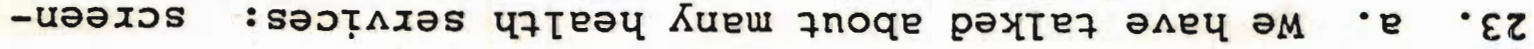




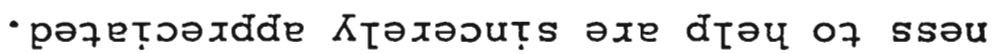

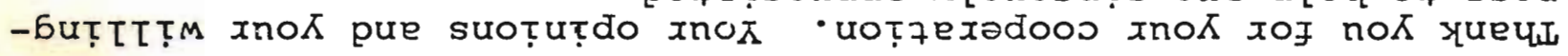

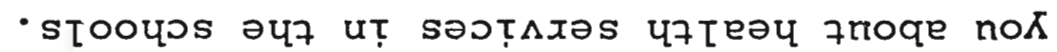

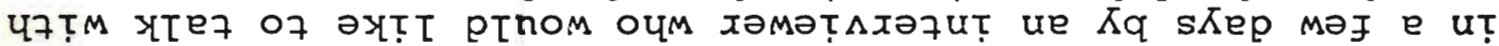

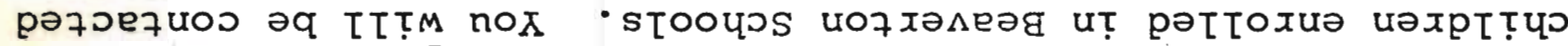

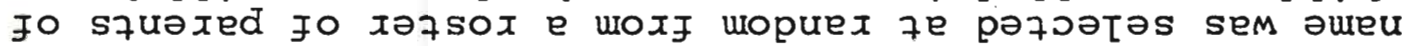

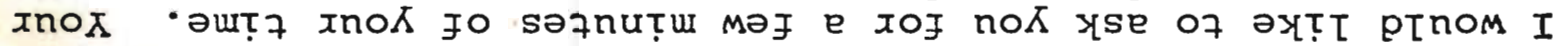

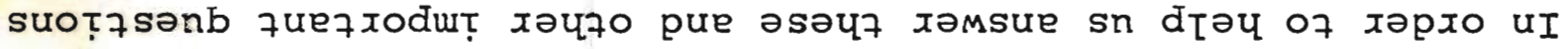

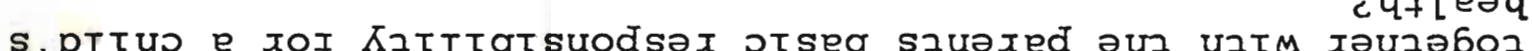

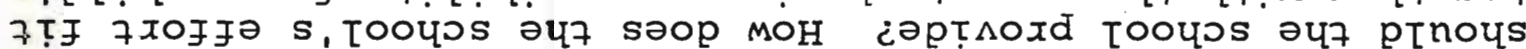

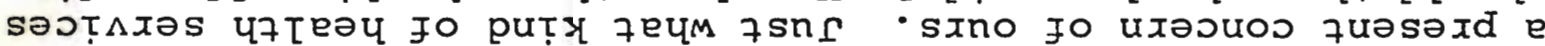

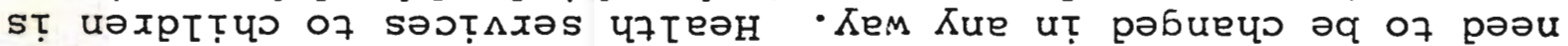

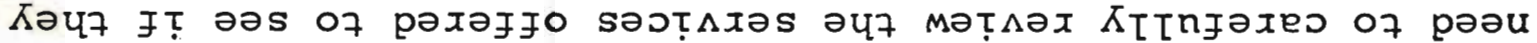

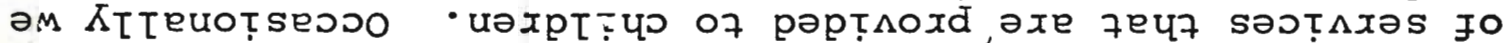

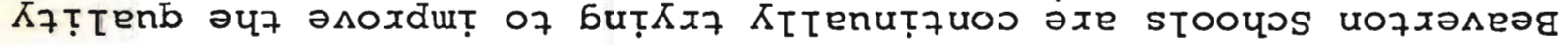


xoțun 07 xәfәx spies әnta 'stooyos Kxequourta of

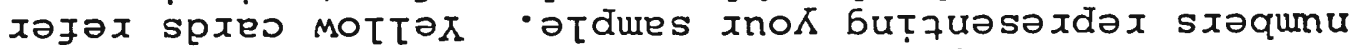

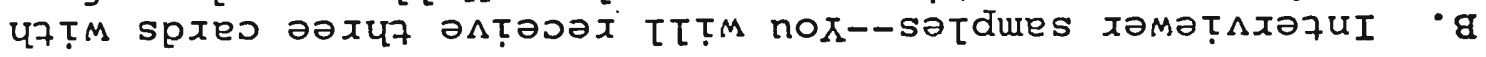

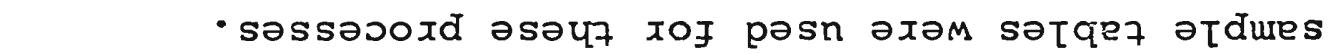

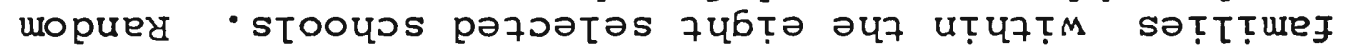

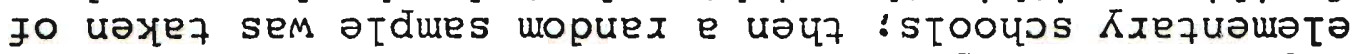

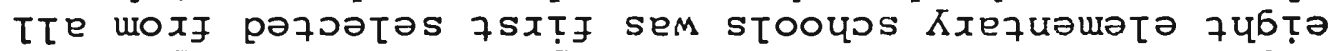

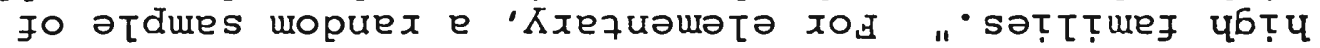

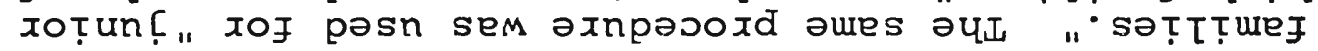

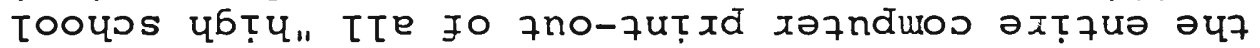

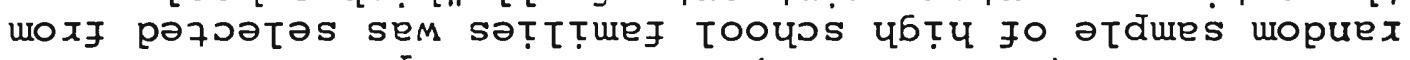

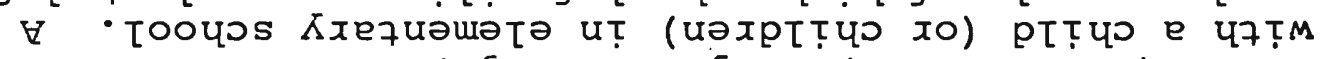

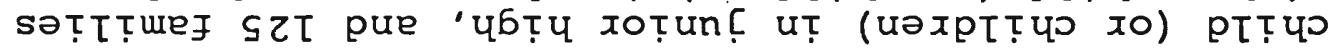

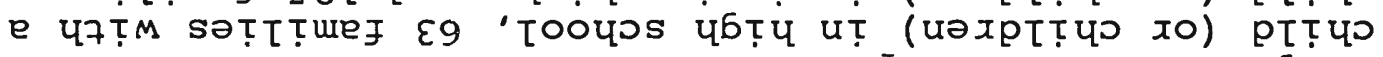

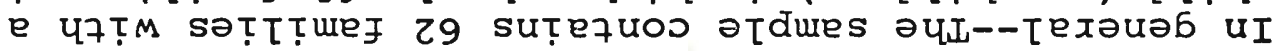

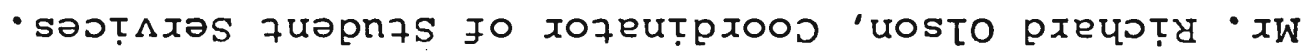

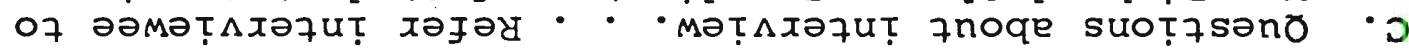

- əsinu e urota ties əuoyd to 7tsta

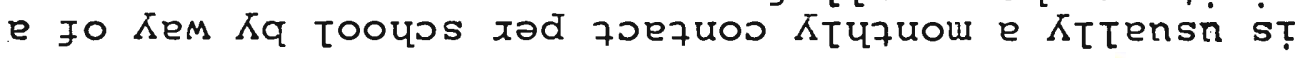

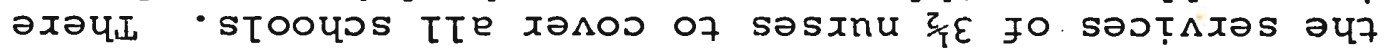

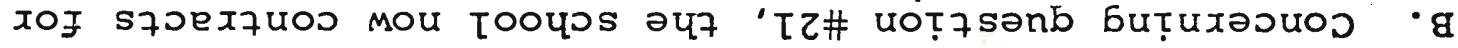

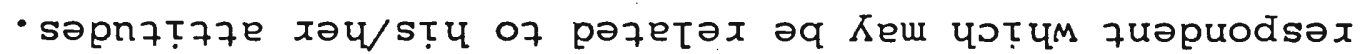

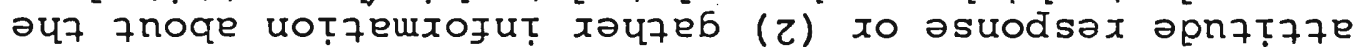

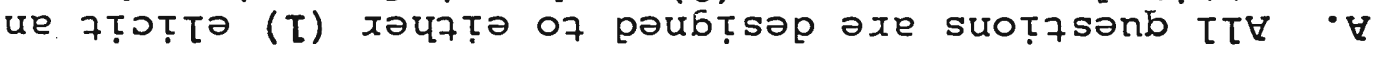

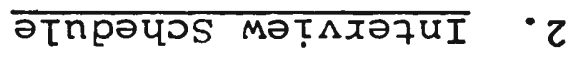

Kq pəzsənbəx sem Kpnzs sṭu山 $\cdot a$

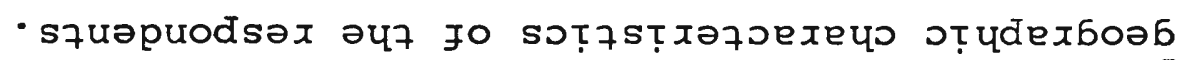

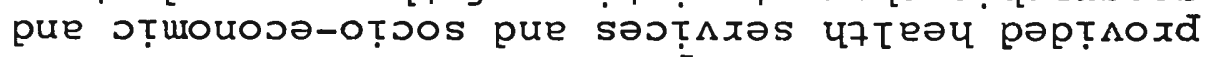

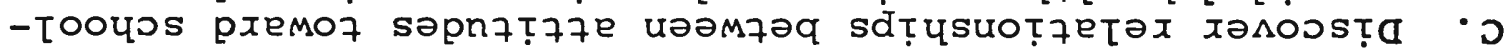

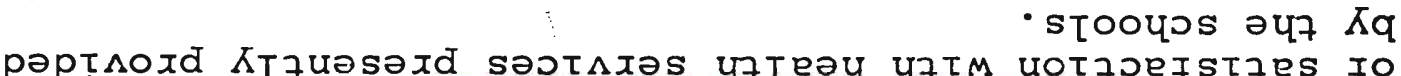
әәхБәр әч7'

- Guṭpț ^oxd

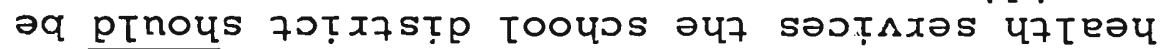

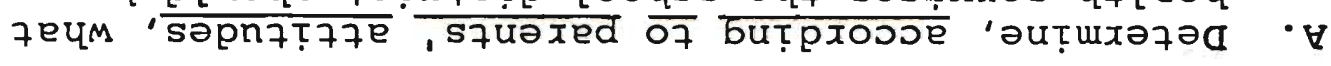




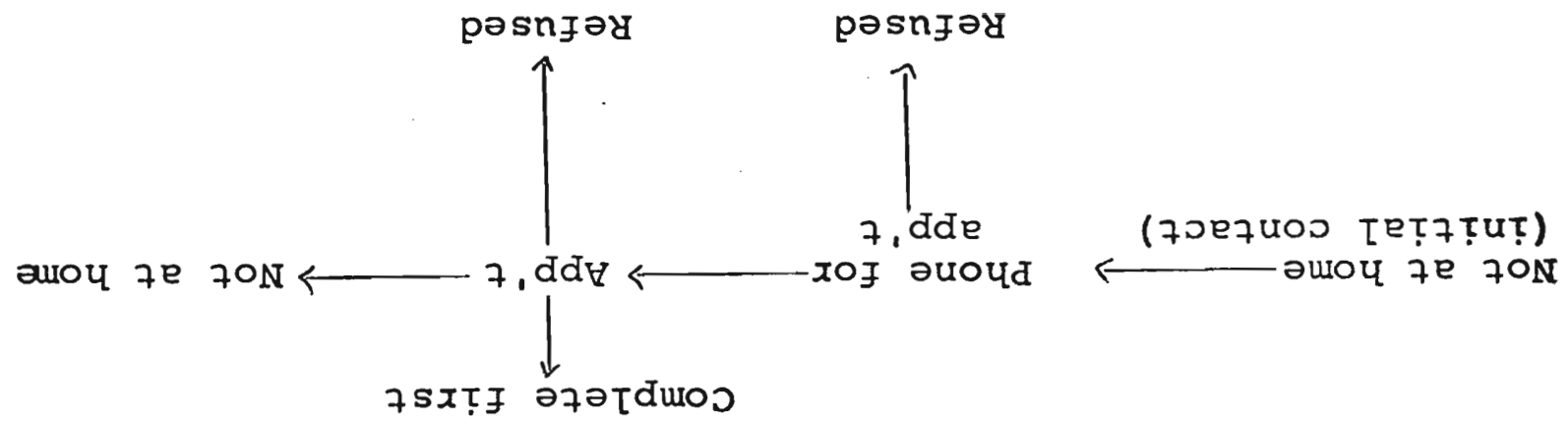

: SMOTTOF se ST SSכDOTd כU7

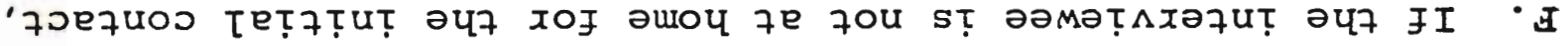

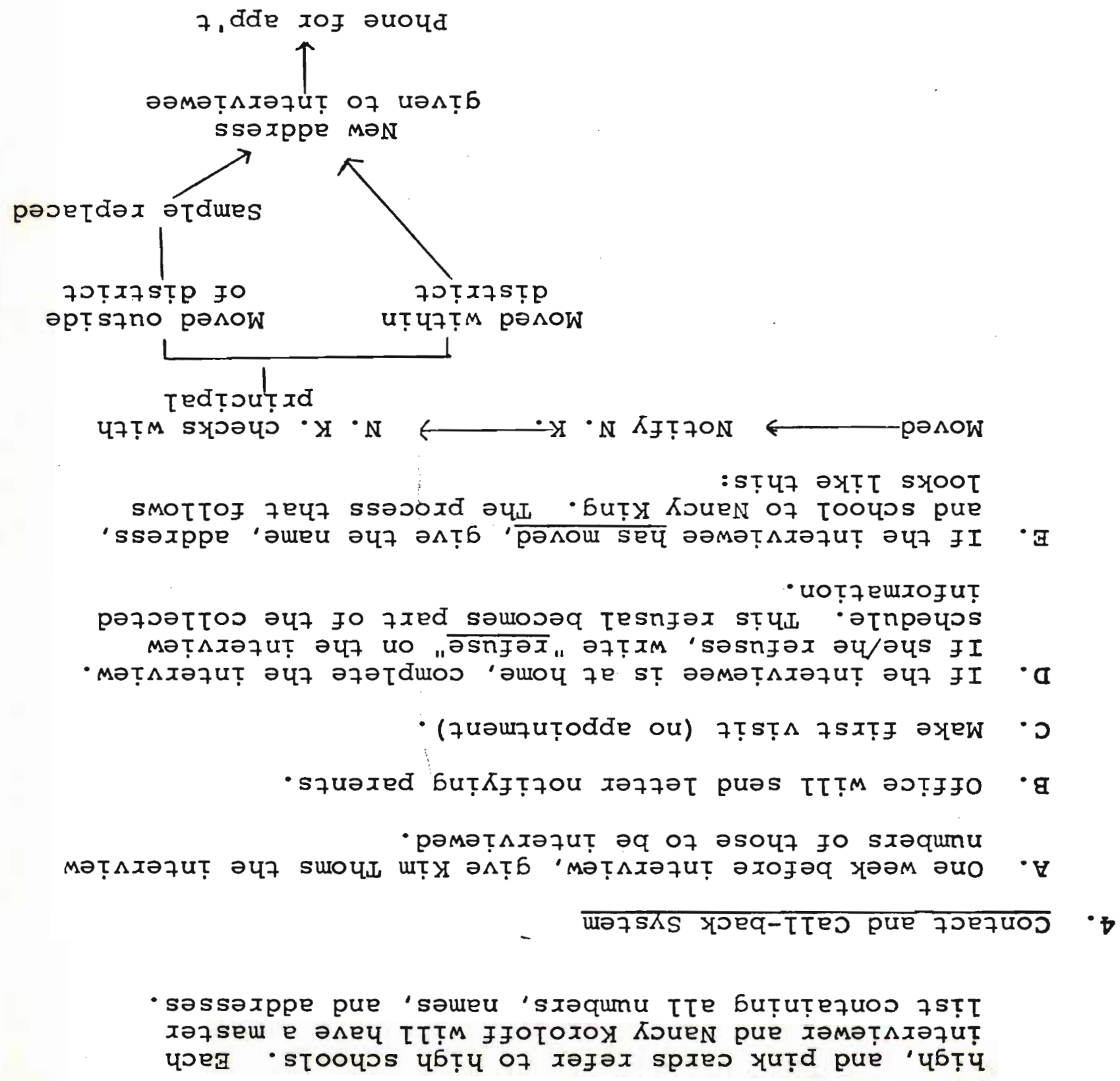


- Euțy Kouen 7oezuos

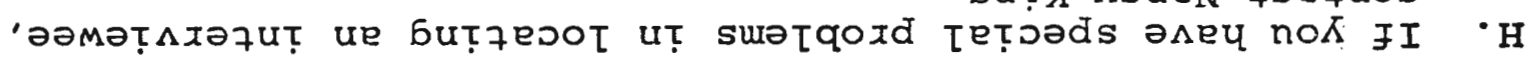

('7uəuquțodde ue әbuexxe of Kx子

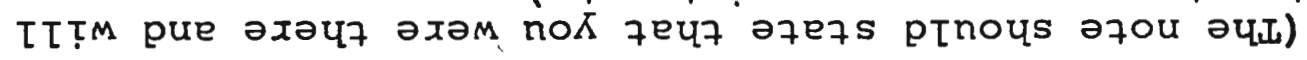

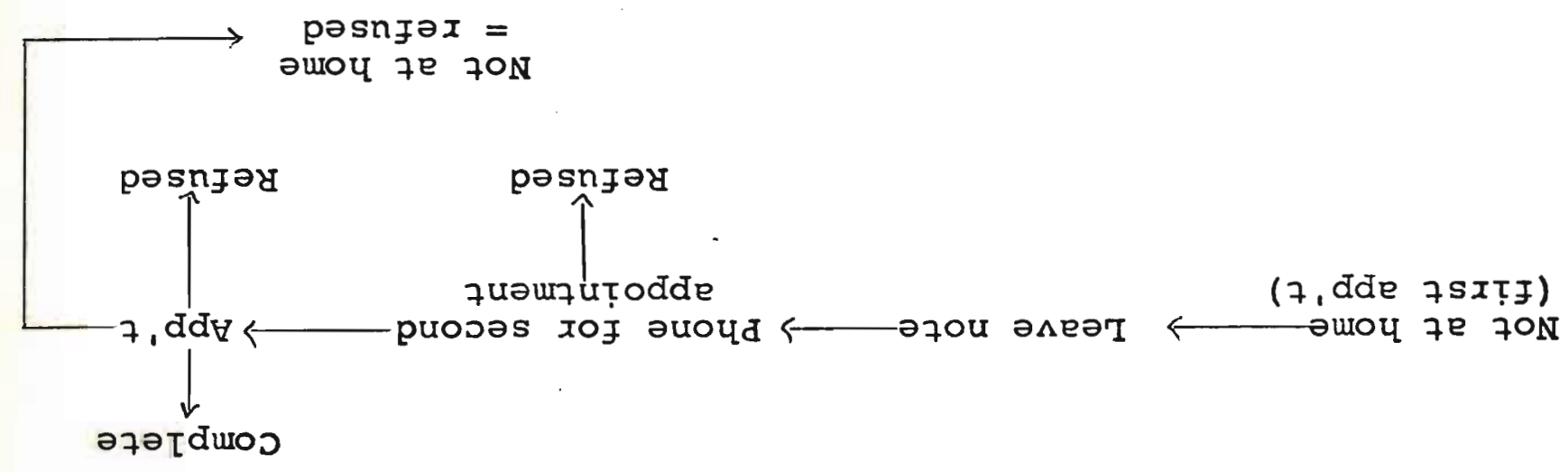

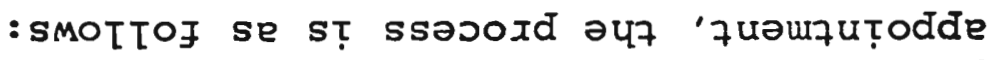

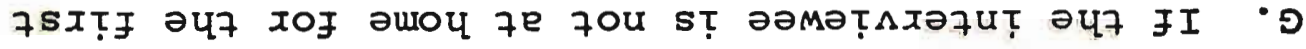

$6 S$ 


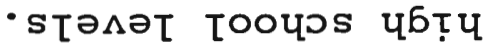

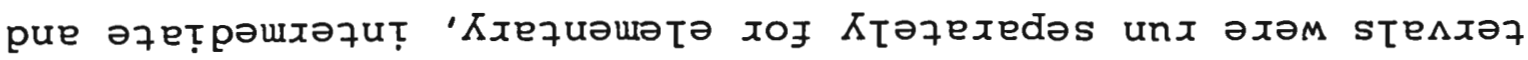

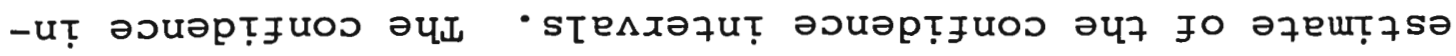

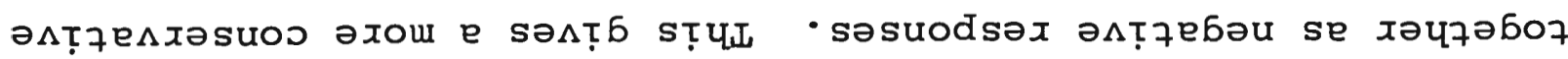
pədunt әләм səт̣лоБә7ер "Moux 7 , uop" pue ' "əsuodsəx ou " "ON"

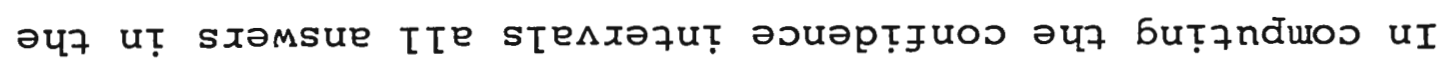

• ə7 eurt 7 sə

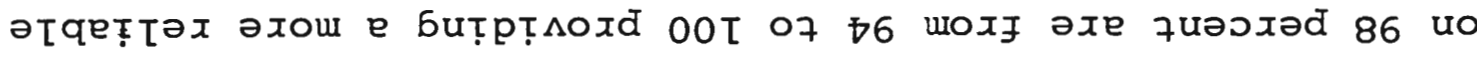

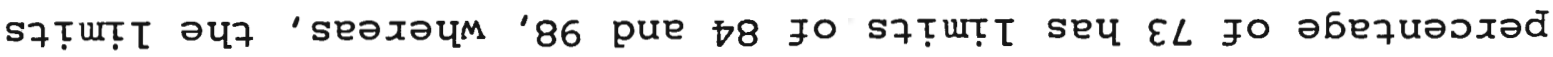

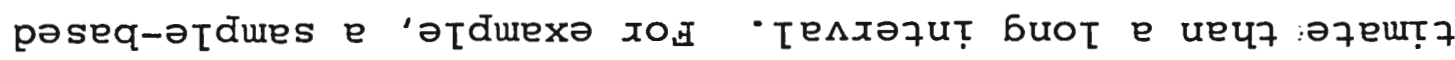

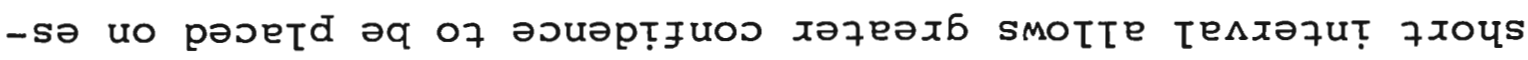

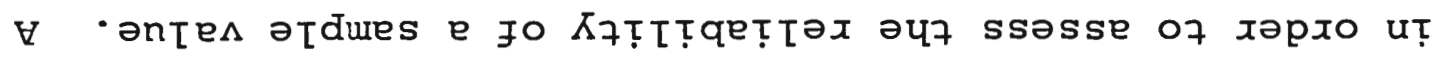

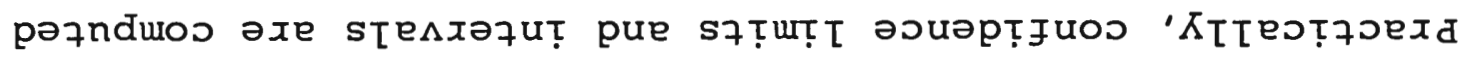

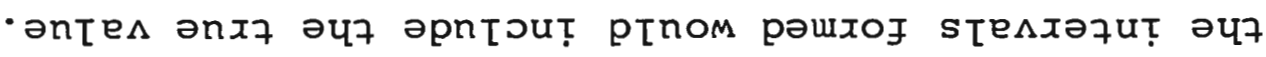
‡o \%

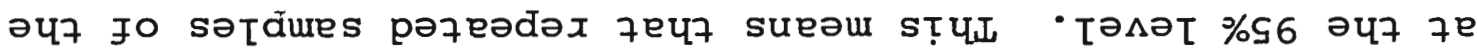

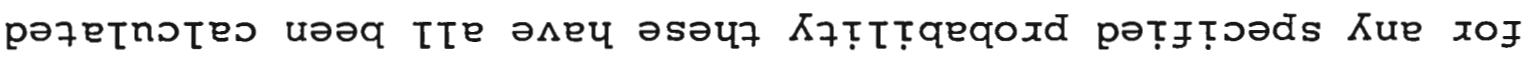

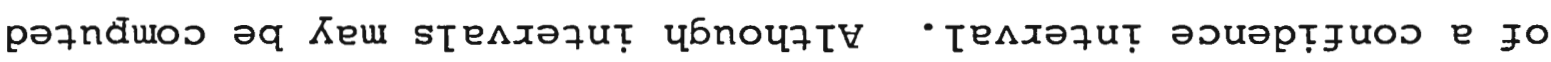

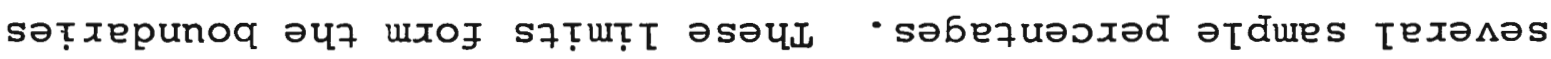

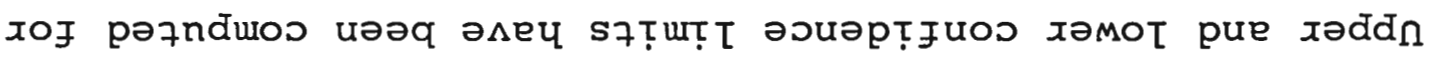

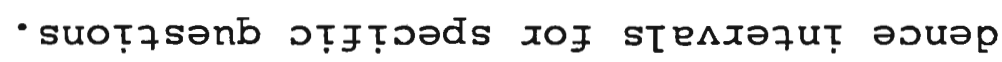

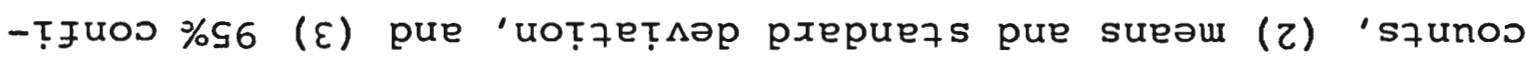

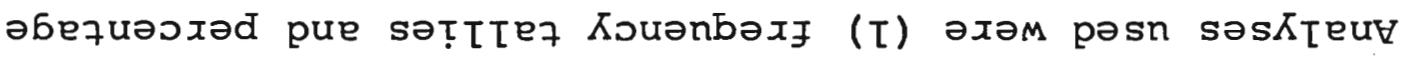

\section{ए7ed fo stskteut}

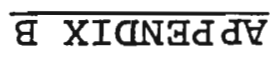




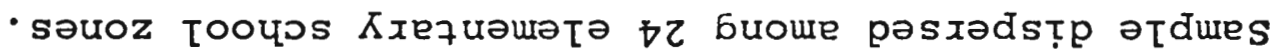

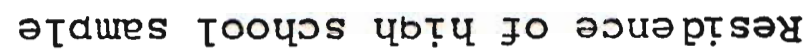

- səuoz tooyos Kxequəurta $\varepsilon$ buoure pəsxədstp әтdures

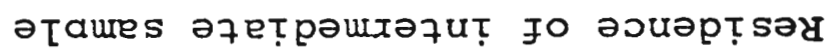

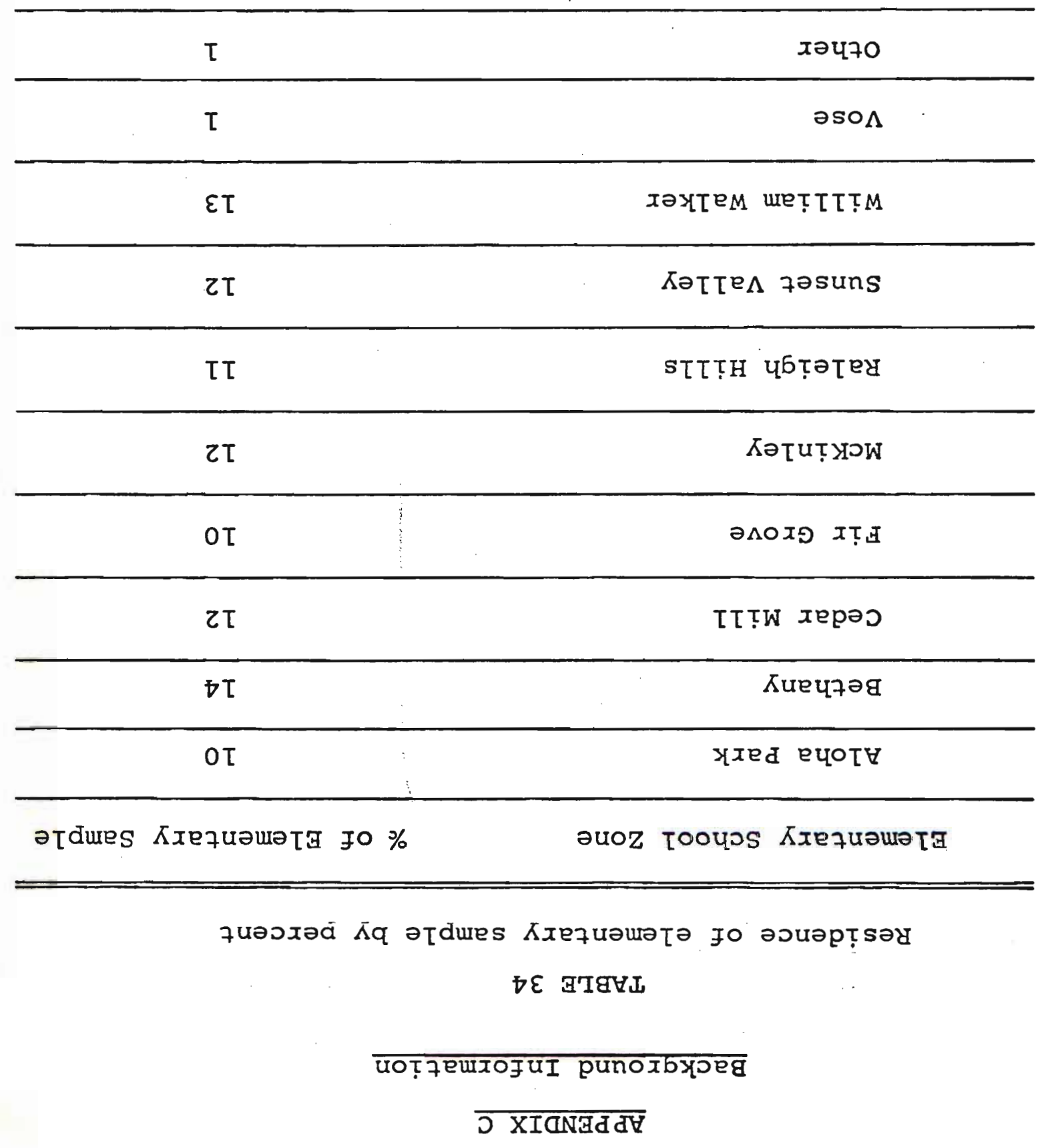




\begin{tabular}{|c|c|c|c|}
\hline-- & -- & $\tau$ & $\partial \Lambda T A$ \\
\hline-- & -- & $\bar{\tau}$ & xnOA \\
\hline-- & -- & $2 T$ & 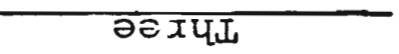 \\
\hline$L L$ & $\varepsilon \tau$ & $L \varepsilon$ & $O M I$ \\
\hline$L L$ & $9 L$ & 67 & จน์ \\
\hline $\begin{array}{c}\text { कTdues } \\
\text { Tooyss } 46 \text { ? } \mathrm{H}\end{array}$ & $\begin{array}{c}\text { әтdures } \\
\text { ә7ет pəuाлә7uI } \\
\%\end{array}$ & 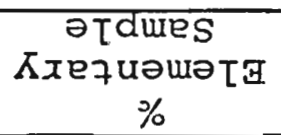 & นəTอโโบว $\overline{\text { JO }} \cdot \mathrm{ON}$ \\
\hline
\end{tabular}

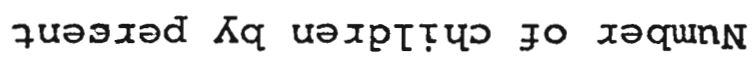

$9 \varepsilon$ जTRHL

\begin{tabular}{|c|c|c|c|}
\hline$\tau$ & $\tau$ & $\tau$ & əsuodsəy ON \\
\hline$\tau$ & - & $\varepsilon$ & Хәч70 \\
\hline 96 & $86^{\circ}$ & $\varepsilon 6$ & ә7т पM \\
\hline 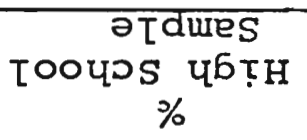 & $\begin{array}{c}\text { әтdures } \\
\text { ә7етрәuхә7uI } \\
\%\end{array}$ & $\begin{array}{c}\text { әTdures } \\
\text { Kxequəur TG } \\
\%\end{array}$ & วऽएप \\
\hline
\end{tabular}

quəsxəd Kq quəpuodsəx fo әреч

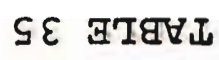




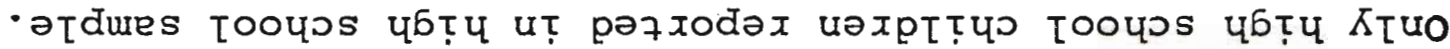

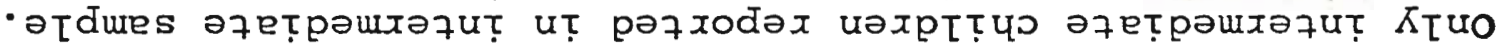

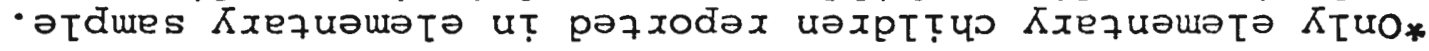

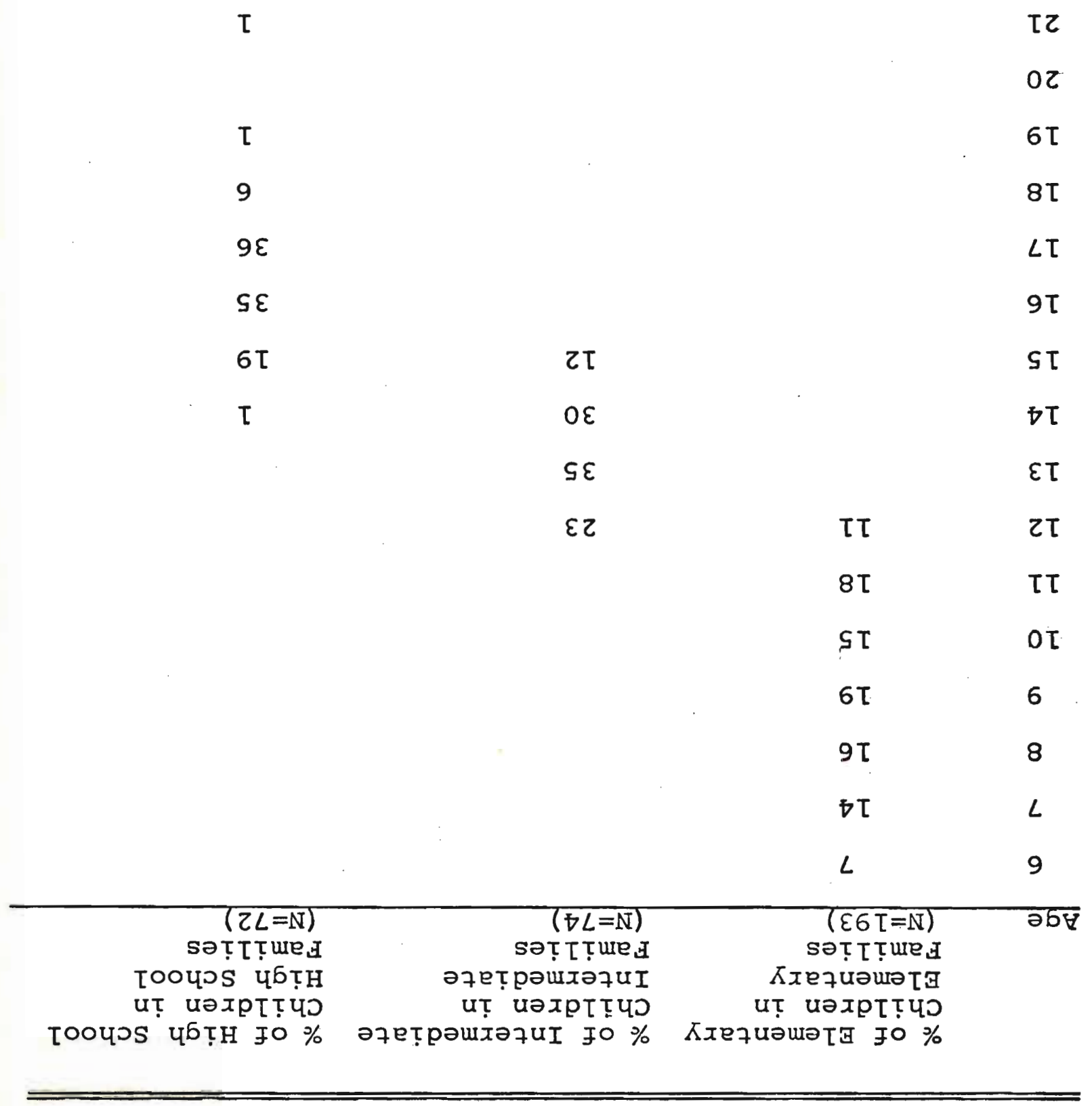

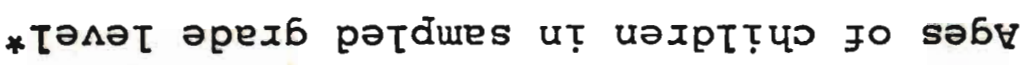
LE TTRQUL 


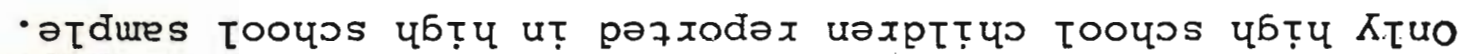

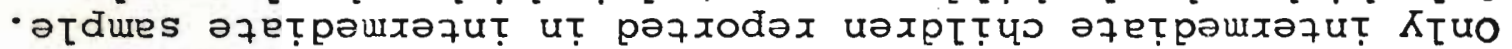

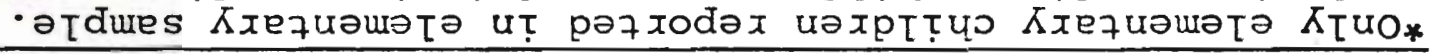

\begin{tabular}{|c|c|c|c|}
\hline$\varepsilon \varepsilon$ & & & $\tau \tau$ \\
\hline$\varsigma \varepsilon$ & & & $\tau T$ \\
\hline$\tau \varepsilon$ & & & OT \\
\hline & $\angle Z$ & & 6 \\
\hline & $\varsigma \varepsilon$ & & 8 \\
\hline & $8 \varepsilon$ & & $L$ \\
\hline & & $6 \tau$ & 9 \\
\hline & & $8 \mathrm{~T}$ & $S$ \\
\hline & & $9 \tau$ & $\square$ \\
\hline & & $8 \tau$ & $\varepsilon$ \\
\hline & & $\varsigma \tau$ & $\tau$ \\
\hline & & $\varsigma \tau$ & $\tau$ \\
\hline $\begin{array}{l}*(Z L=N) \\
\text { səț }\{\text { T ues }\end{array}$ & 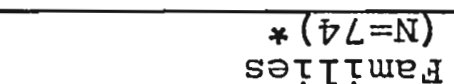 & $\begin{array}{l}*(\varepsilon \sigma \bar{\tau}=\mathrm{N}) \\
\text { səT Ture }\end{array}$ & 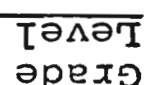 \\
\hline 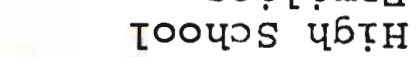 & ә7етุрวนมวานI & 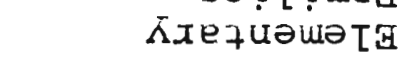 & \\
\hline uṬ uəxptтษ & uTฺ นəxpโтบว & UṬ uəxpโTฺบ & \\
\hline 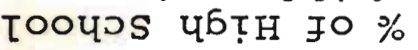 & ә7етрәшіә7иI f० \% & 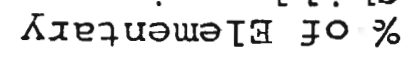 & \\
\hline
\end{tabular}

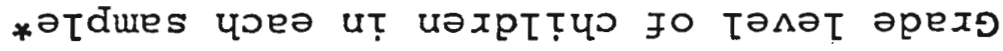

$6 \varepsilon$ अTRष山

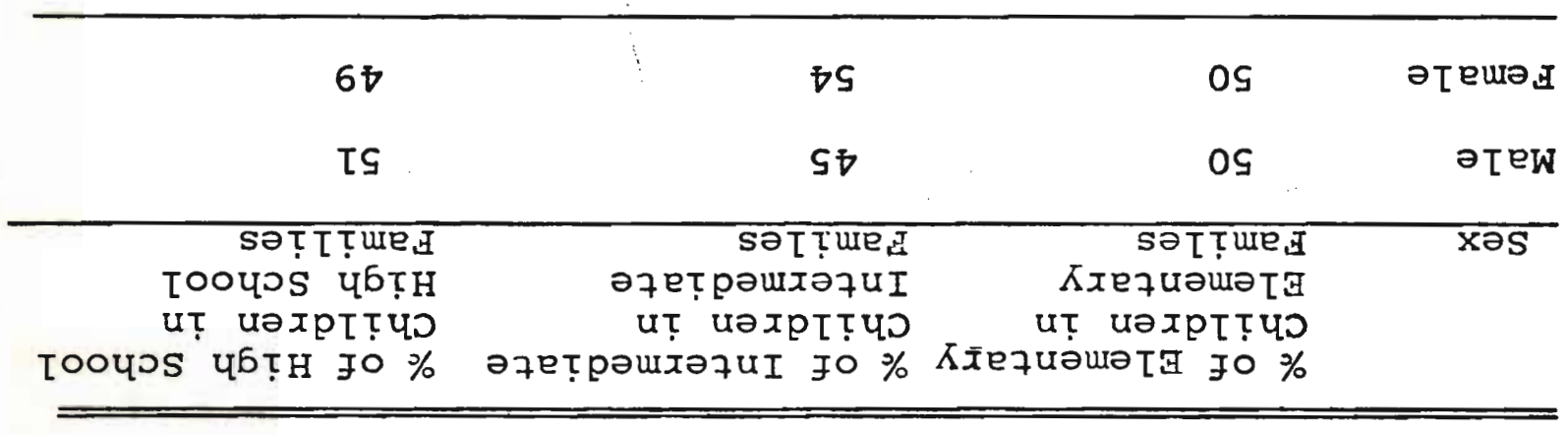

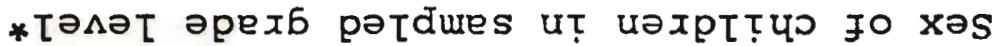

$8 \varepsilon$ घ'TघH山 


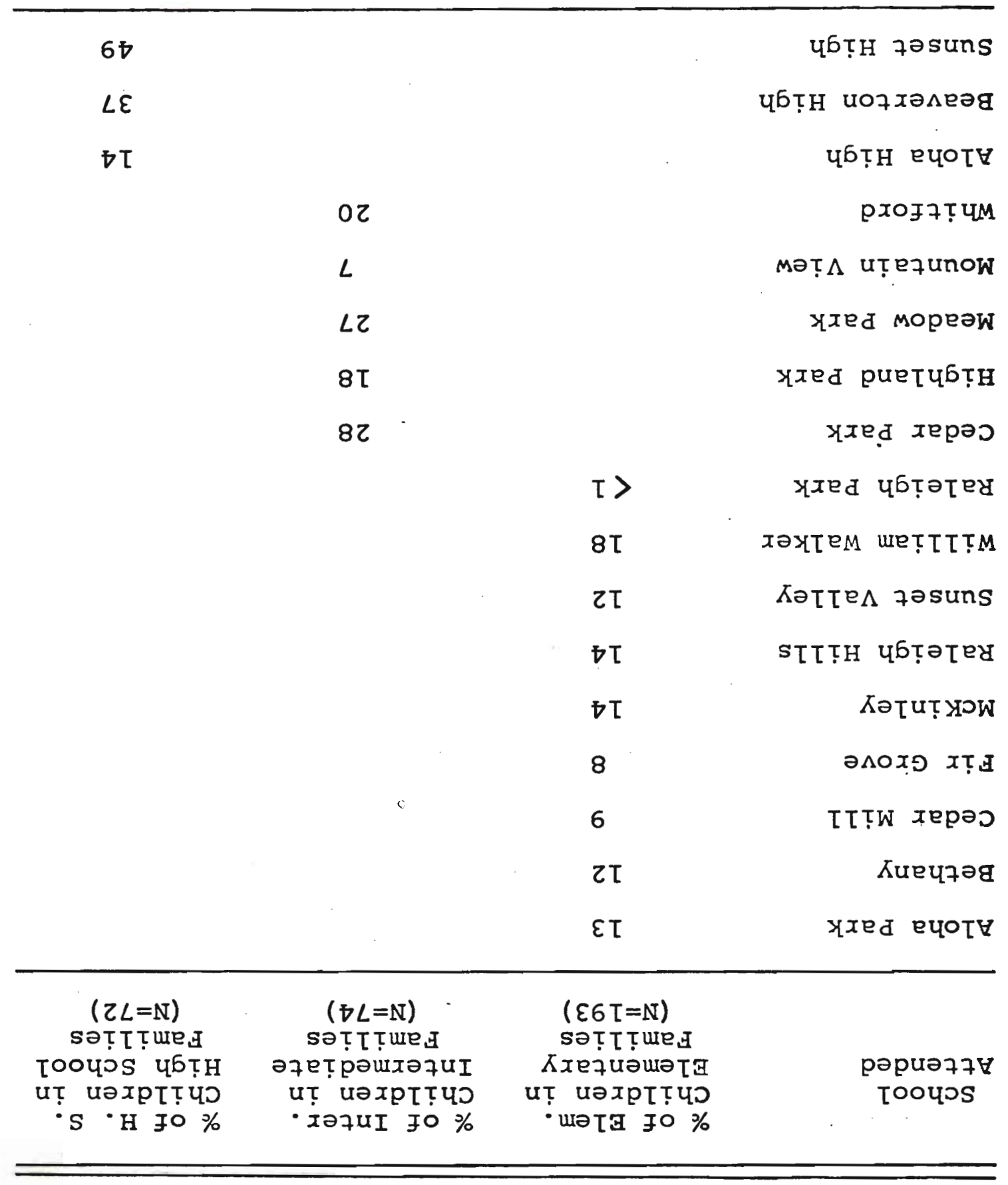

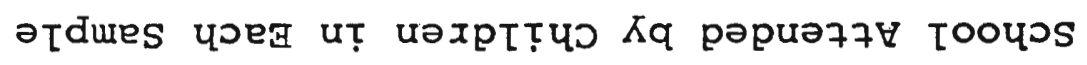

O† अTघH山 


\begin{tabular}{|c|c|c|c|}
\hline & $\tau$ & & 8 \\
\hline \multirow[t]{2}{*}{$\varepsilon$} & $\tau$ & & $L$ \\
\hline & $\tau$ & $\tau>$ & 9 \\
\hline$\varsigma$ & 9 & $\varsigma$ & $\varsigma$ \\
\hline OT & 8 & $S \mathrm{I}$ & $\nabla$ \\
\hline$S T$ & 82 & $\tau \varepsilon$ & $\varepsilon$ \\
\hline 七t & $9 \varepsilon$ & $6 \varepsilon$ & $\tau$ \\
\hline 乙乙 & $\varsigma \tau$ & 9 & $\tau$ \\
\hline әтdures & әтdures & әтdures & $\begin{array}{l}\text { sfrnpy } \\
\text { IכounN }\end{array}$ \\
\hline
\end{tabular}

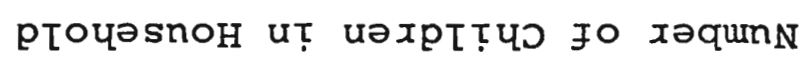

てヤ अभघषU

\begin{tabular}{|c|c|c|c|}
\hline$\varepsilon$ & $\varepsilon$ & & $\nabla$ \\
\hline$\varepsilon \tau$ & $O \tau$ & 9 & $\varepsilon$ \\
\hline$Z L$ & $\varepsilon L$ & $\angle 8$ & $\tau$ \\
\hline $0 \mathrm{~T}$ & $\varepsilon \tau$ & 9 & $\tau$ \\
\hline 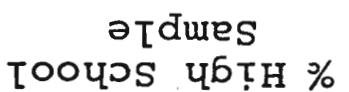 & $\begin{array}{c}\text { әтdures } \\
\text { ә7етрәuхә7uI \% }\end{array}$ & $\begin{array}{c}\text { ətdures } \\
\text { Kxequəurtg \% }\end{array}$ & $\begin{array}{c}\text { s7tnpy } \\
\text { go rəqumn }\end{array}$ \\
\hline
\end{tabular}

pтoyəsnoH uṬ s7tnpH fo xəqunN

T万 BTR甘山 


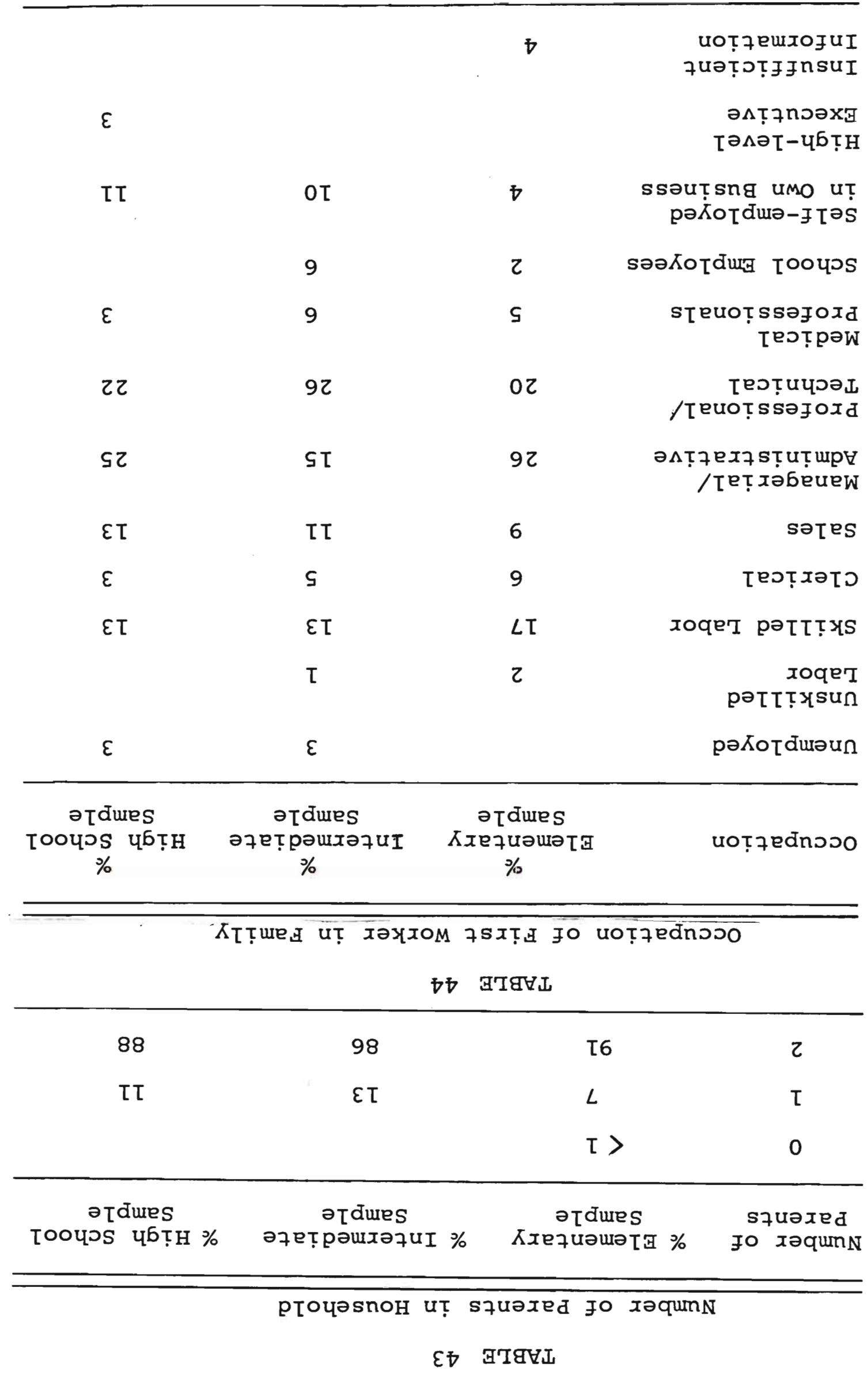




\begin{tabular}{|c|c|c|c|}
\hline & & $\tau$ & 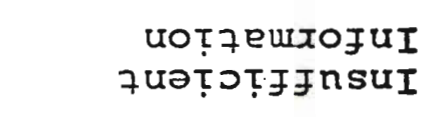 \\
\hline$\tau$ & & & 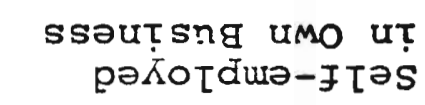 \\
\hline$\tau$ & $\tau$ & $\varepsilon$ & səəKం โdurg TOOYDS \\
\hline$\tau$ & $\tau$ & $\tau>$ & $\begin{array}{r}\text { Leotpan } \\
\text { steuotscojoxd }\end{array}$ \\
\hline$\varepsilon \tau$ & 8 & $\tau$ & $\begin{array}{r}\text { Tesțuyoad } \\
\text { / teuoțsajoxd }\end{array}$ \\
\hline$\tau$ & & $\tau$ & 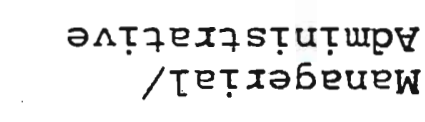 \\
\hline 9 & $\tau$ & $\tau$ & sotes \\
\hline OT & $\varepsilon$ & 9 & โอวtรวโว \\
\hline \multirow[t]{2}{*}{$\tau$} & $\varepsilon$ & $\tau$ & xоqет рәтттXS \\
\hline & & $\tau \tau$ & $\begin{array}{r}\text { roqet } \\
\text { pərt? ysun }\end{array}$ \\
\hline โ9 & 08 & $O L$ & əsuodsoy oN \\
\hline 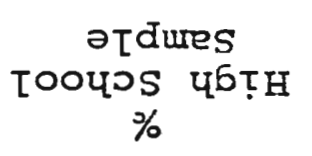 & $\begin{array}{c}\text { ə๘dures } \\
\text { ә7ет pəurxə7uI } \\
\%\end{array}$ & 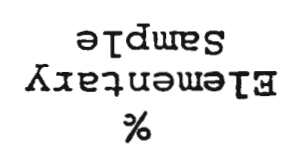 & Uoṭzednoso \\
\hline
\end{tabular}

Ktт়ure

St GTRUI 


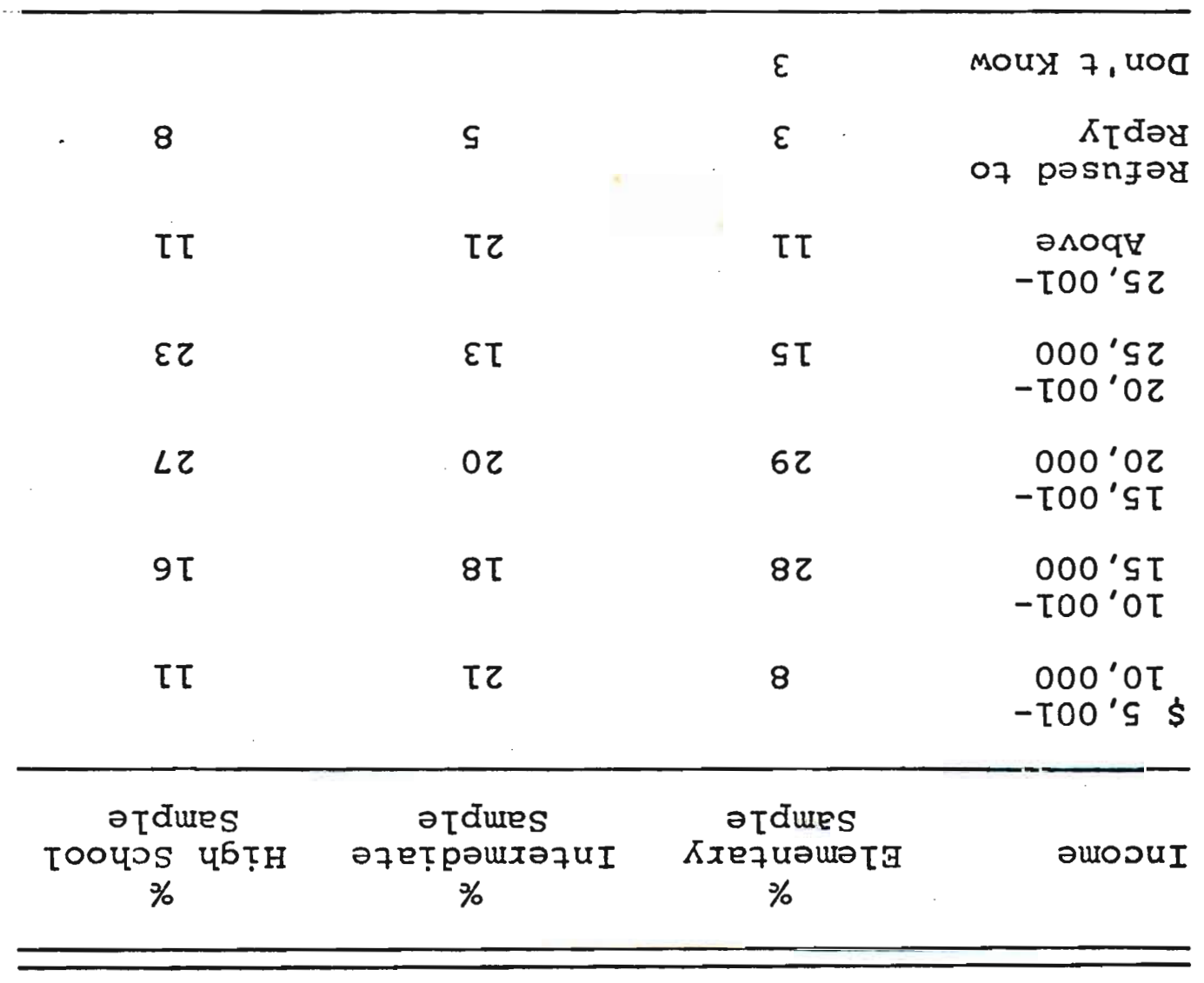

əurosuI KIṬueg Tenuur 7uəsəxd

97 अ्रTघस山 


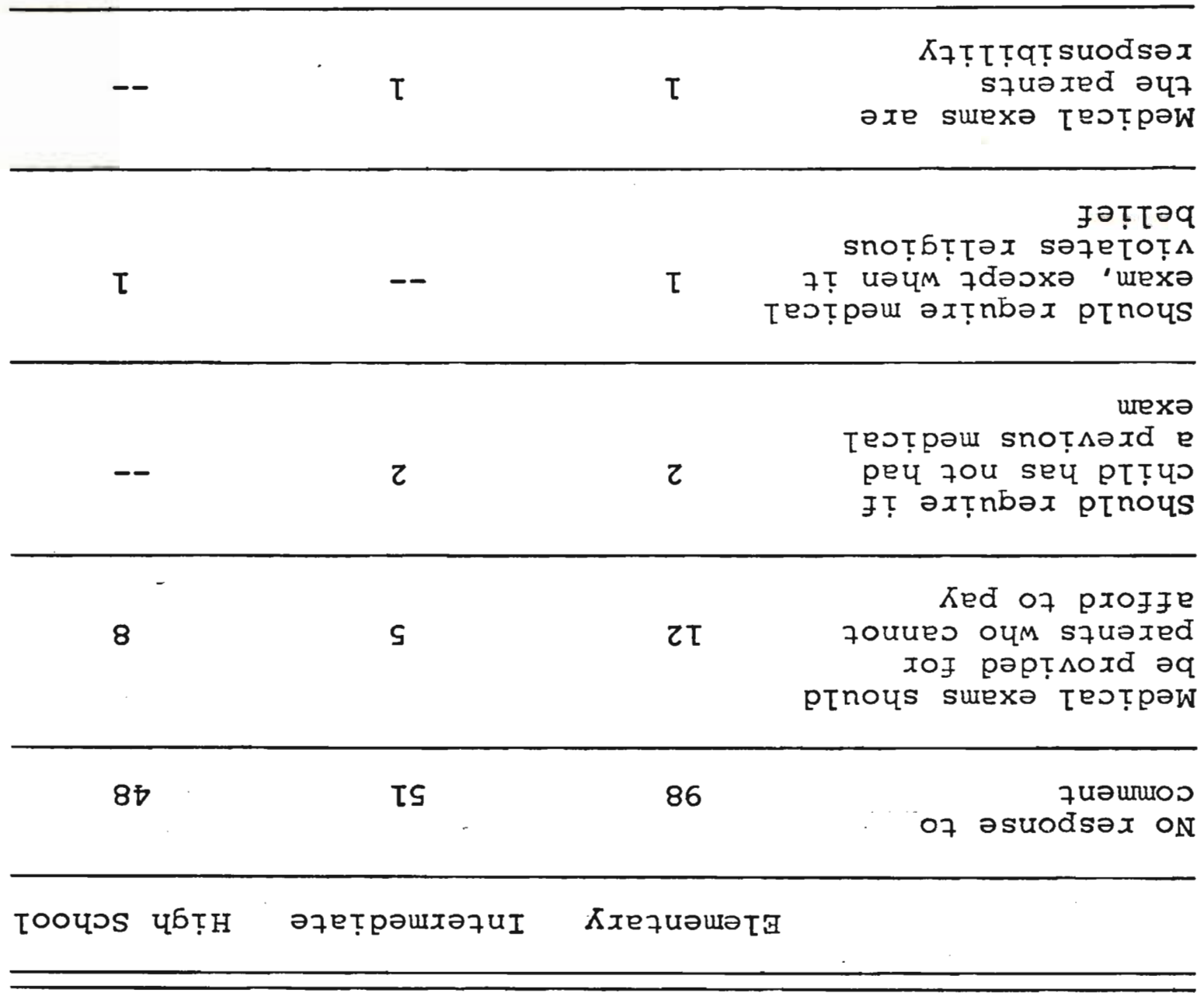

s7uәpn7s әрето $75 x$ ț

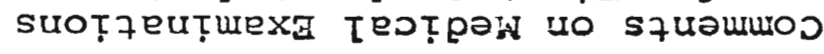

L7 अTgVU

Suoț7euțuexg TesṭpoW

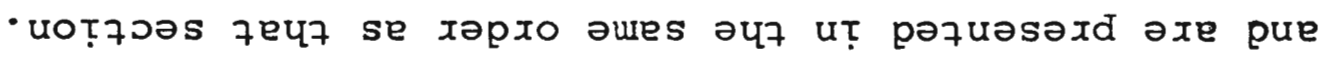

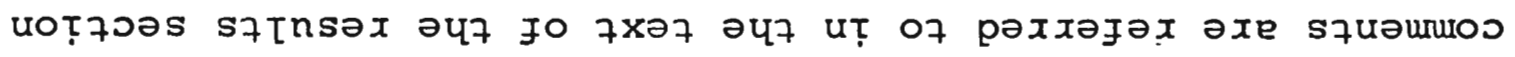

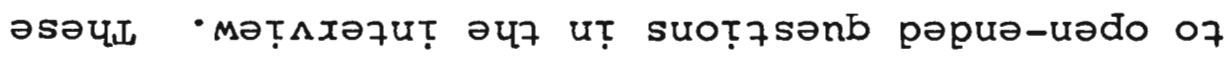

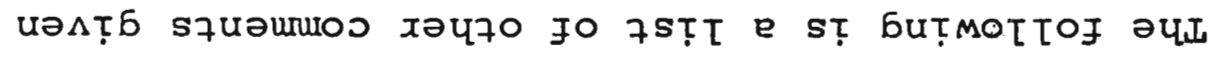

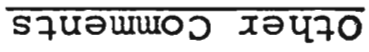

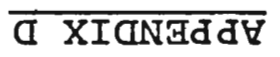




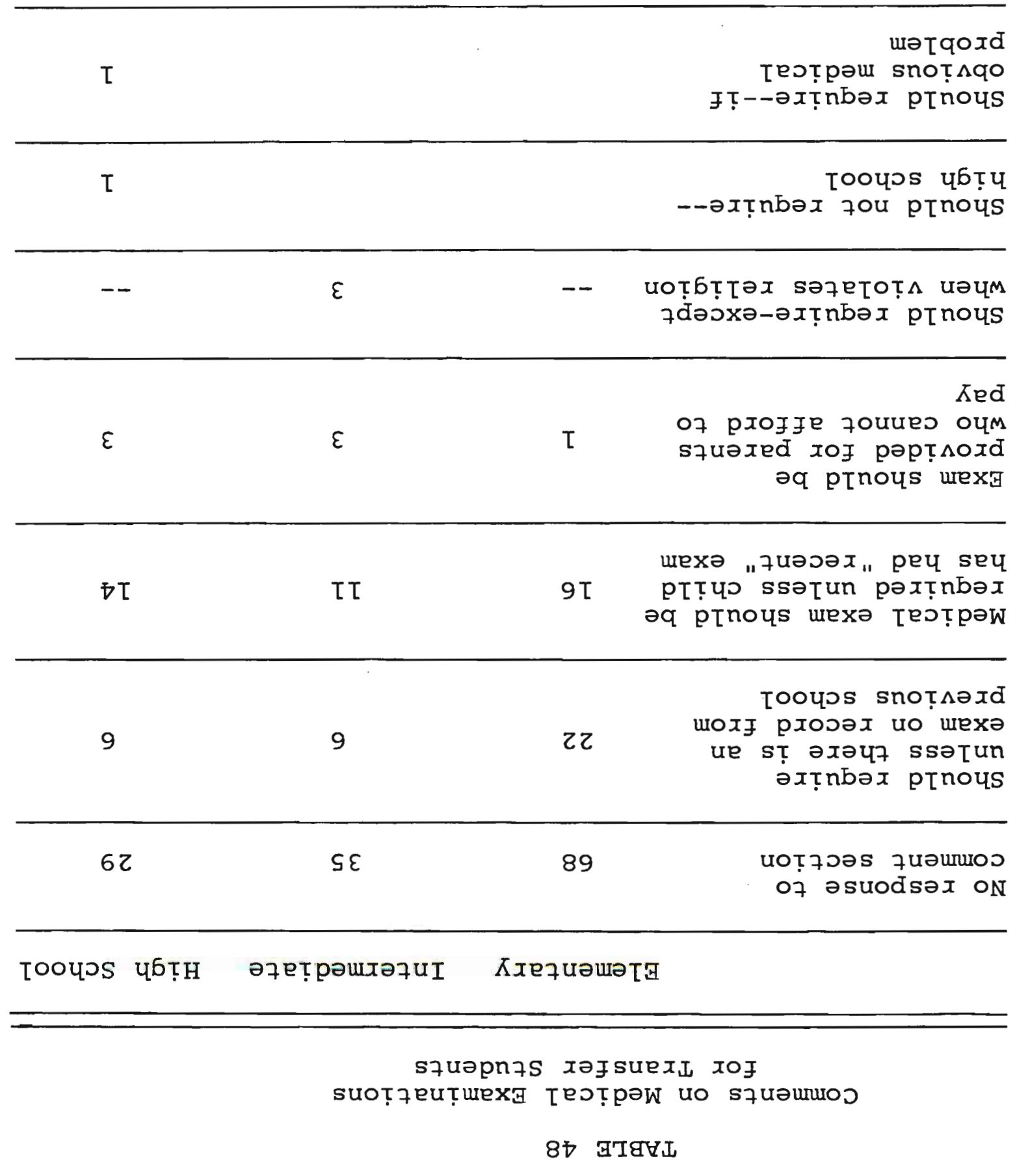

TL 


\begin{tabular}{|c|c|c|c|c|}
\hline & & & $\tau$ & 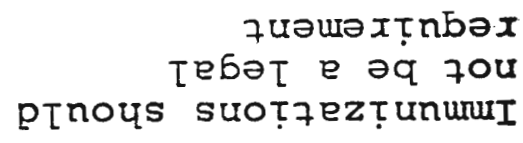 \\
\hline & & & $\varepsilon$ & 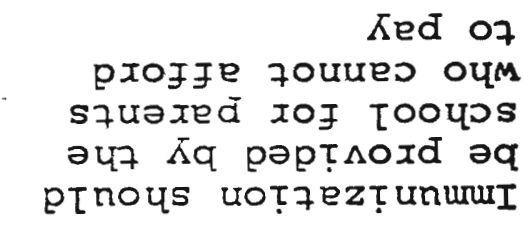 \\
\hline \multirow[t]{2}{*}{$\tau$} & $\tau$ & 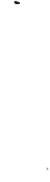 & $\tau$ & 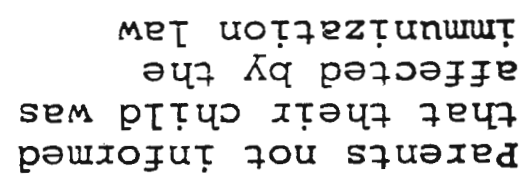 \\
\hline & $\tau$ & & $\varepsilon$ & 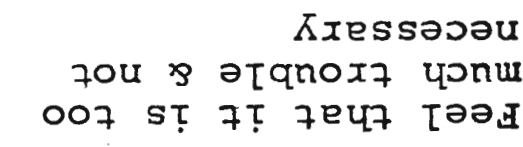 \\
\hline 9 & $S$ & 0 & OE & 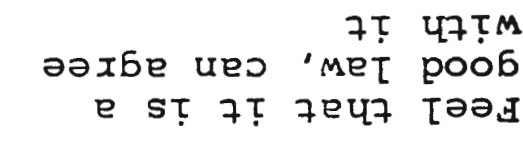 \\
\hline$\tau$ & 0 & & $\mathbf{\tau}$ & $\begin{array}{l}\text { uoț7Dəs } 7 \text { uəururo } \\
\text { of səsuodsəx }\end{array}$ \\
\hline
\end{tabular}

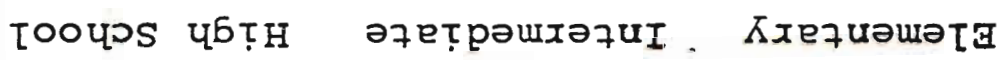

MET uoț7ezṬunururT

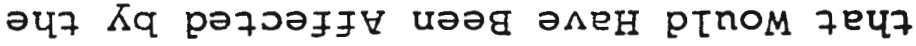

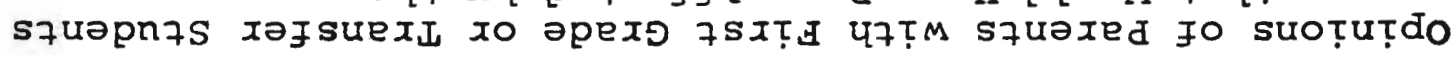

6D अTघサ山

suoț7ezṬunurur

ZL 


\begin{tabular}{|c|c|c|c|}
\hline $\mathrm{T}$ & 0 & 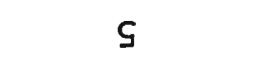 & хәч70 \\
\hline$\tau$ & 0 & 0 & $\begin{array}{r}\text { surtcoxd } \\
\text { texoț } 1 \text { yog } \\
\text { / teuot 7our }\end{array}$ \\
\hline$\tau$ & 0 & $\tau$ & sәpexD rood \\
\hline 0 & 0 & 2 & 6uт̣xeән \\
\hline 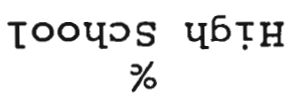 & $\begin{array}{c}\text { ә7етрәихә7и I } \\
\%\end{array}$ & $\begin{array}{c}\text { Xxequourəโ马 } \\
\%\end{array}$ & \\
\hline
\end{tabular}

"ə^eH ptnoys " 7nq

squəxed of uriqoxd S,PITY0 7xodəy 07

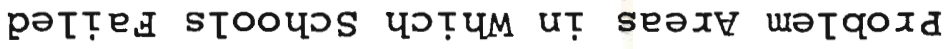

OS GTRZय 


\begin{tabular}{|c|c|c|c|c|}
\hline $\begin{array}{l}\tau \\
\tau \\
\tau \\
\tau \\
0 \\
0\end{array}$ & $\begin{array}{l}\tau \\
Z \\
2 \\
2 \\
Z \\
\tau\end{array}$ & $\begin{array}{l}\tau \\
\tau \\
\varepsilon \\
\tau \\
0 \\
0\end{array}$ & 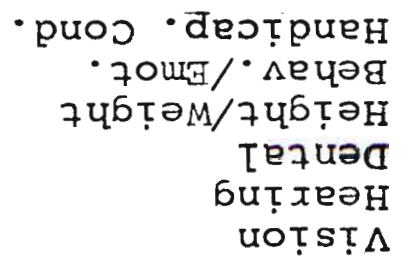 & 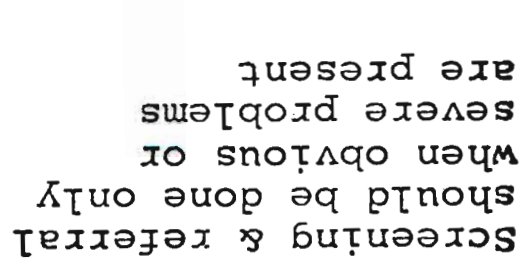 \\
\hline $\begin{array}{l}0 \\
\tau \\
\tau \\
0 \\
0 \\
0\end{array}$ & $\begin{array}{l}\tau \\
0 \\
0 \\
\tau \\
\tau \\
0\end{array}$ & $\begin{array}{l}\mathrm{T} \\
0 \\
\mathrm{\tau} \\
\mathrm{T} \\
0 \\
0\end{array}$ & 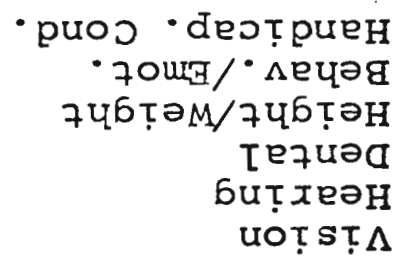 & 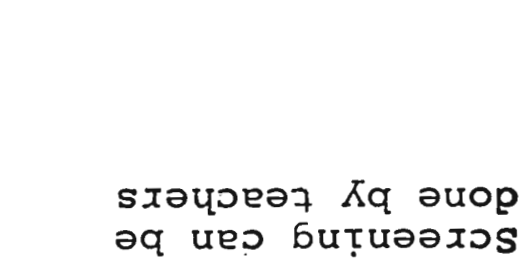 \\
\hline $\begin{array}{l}0 \\
\tau \\
0 \\
0 \\
0 \\
\tau\end{array}$ & $\begin{array}{l}0 \\
\tau \\
0 \\
0 \\
0 \\
0\end{array}$ & $\begin{array}{l}\square \\
9 \\
\tau \\
7 \\
S \\
9\end{array}$ & 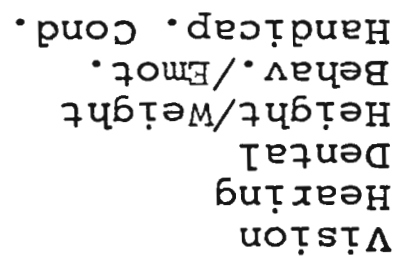 & 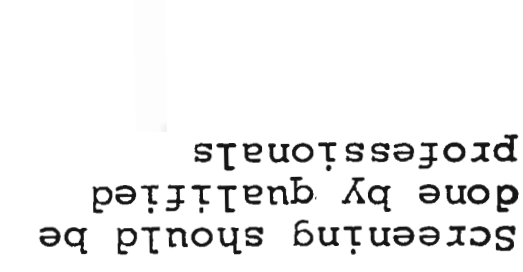 \\
\hline $\begin{array}{l}0 \\
0 \\
0 \\
\tau \\
\tau \\
\tau\end{array}$ & $\begin{array}{l}0 \\
0 \\
0 \\
0 \\
0 \\
0\end{array}$ & $\begin{array}{l}\tau \\
0 \\
Z \\
\tau \\
\tau \\
0\end{array}$ & 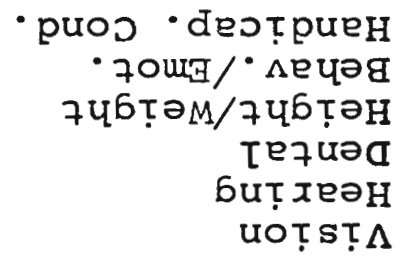 & 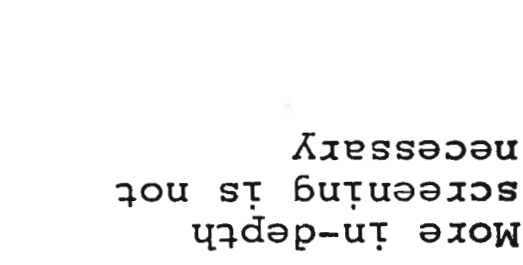 \\
\hline $\begin{array}{l}T \\
0 \\
\tau \\
2 \\
Z \\
0\end{array}$ & $\begin{array}{l}\mathrm{S} \\
0 \\
0 \\
0 \\
\tau \\
\mathrm{T}\end{array}$ & $\begin{array}{l}0 \\
0 \\
0 \\
0 \\
0 \\
0\end{array}$ & 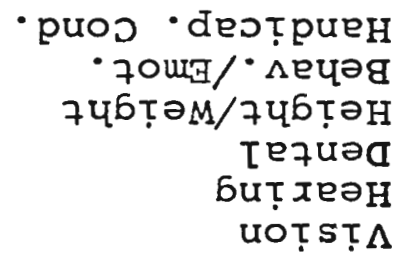 & 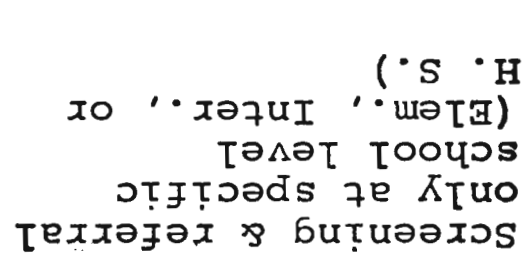 \\
\hline $\begin{array}{l}\cdot \mathrm{S} \cdot \mathrm{H} \\
(\mathrm{s} \partial \mathrm{su}\end{array}$ & $\begin{array}{l}\text { xә7UI } \\
\text { sәd 于0 }\end{array}$ & 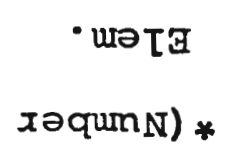 & & \\
\hline
\end{tabular}

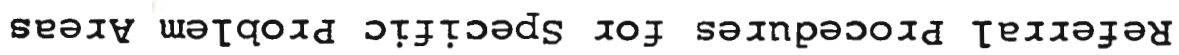

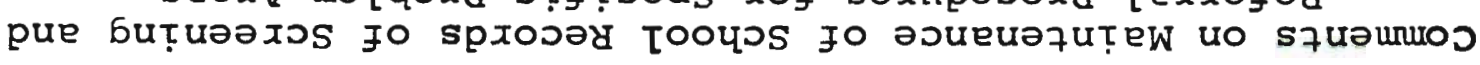
IS G्र'Tgस 


\begin{tabular}{|c|c|c|c|}
\hline $6 \tau$ & $\mathbf{s}$ & 6 & səsuodsəx xəч70 \\
\hline$L$ & 8 & $2 \mathrm{I}$ & 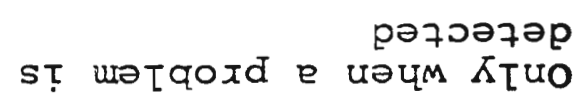 \\
\hline$\underset{\%}{\text { ToOỹs }}$ & $\begin{array}{l}\text { ә7етрәихә7иI } \\
\%\end{array}$ & $\begin{array}{c}\text { Kxequəur TG } \\
\%\end{array}$ & \\
\hline
\end{tabular}

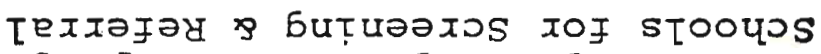

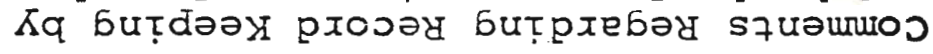

ZS सTघH山

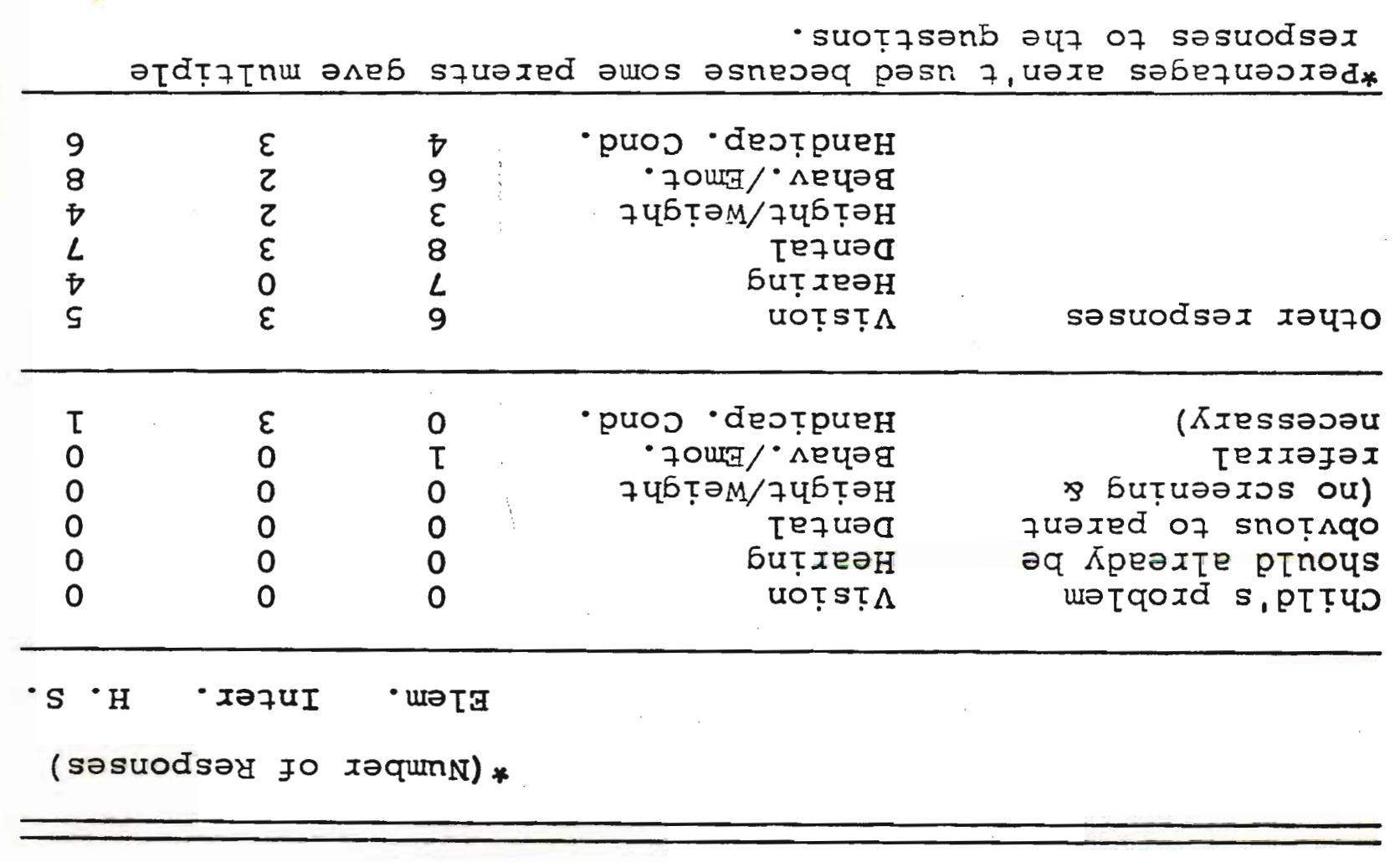




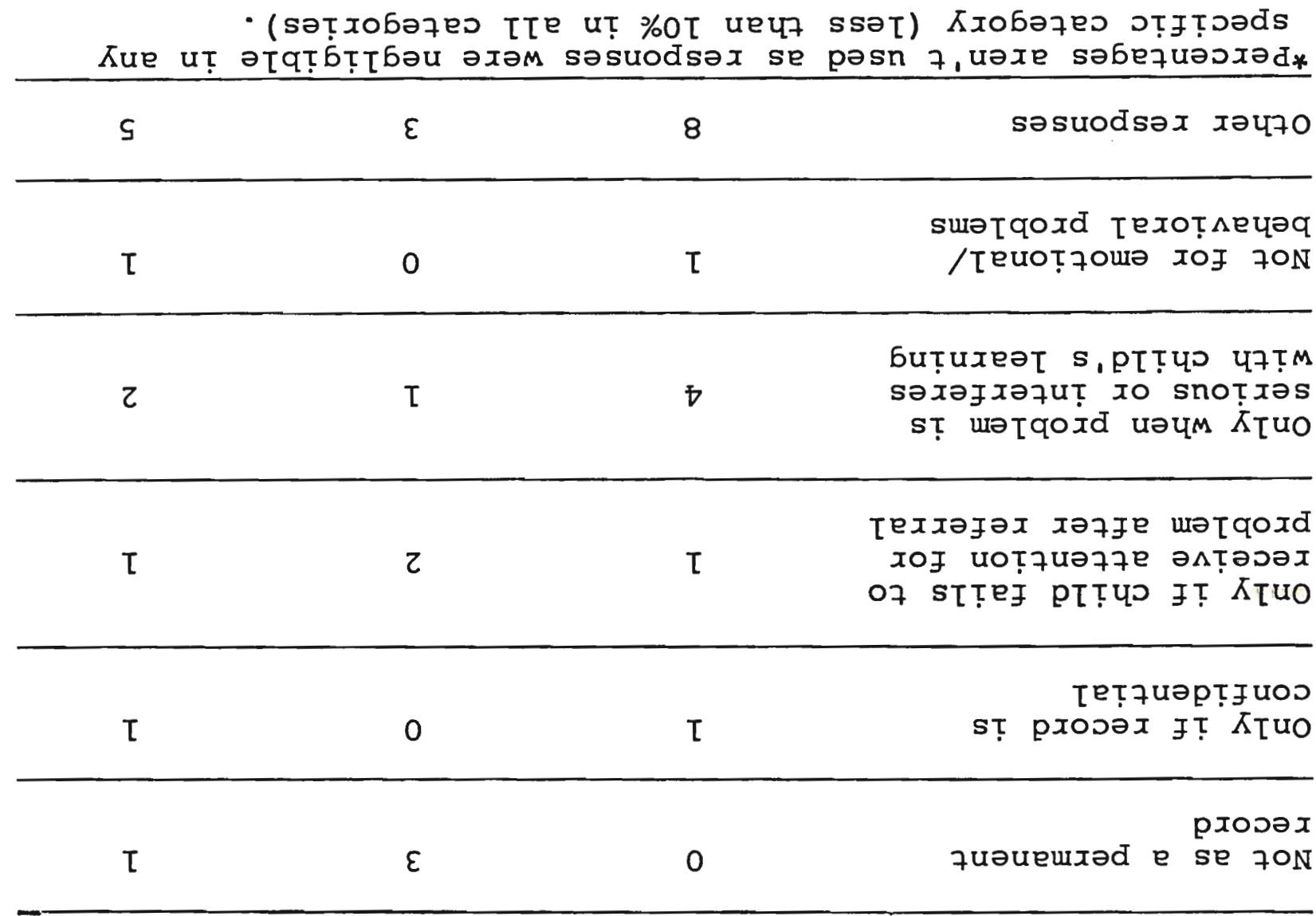

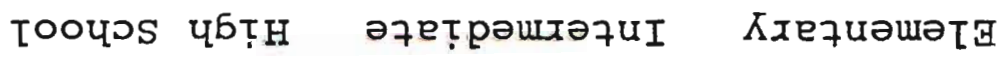

(səsuodsəy Ғo xəqunN) *

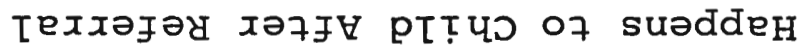

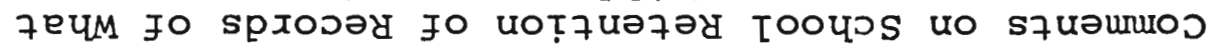

ES GTGH山 
- suoțsənb כu7 07

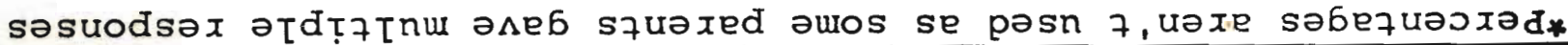
$\mathrm{p} T \mathrm{H}$

62 OT $\quad 5 T$ 75xTH xo!̣ eW

\begin{tabular}{|c|c|c|c|c|c|}
\hline . $\quad \tau \varepsilon$ & $\varepsilon \tau$ & 9 & ZT & 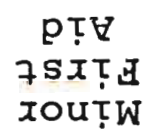 & \\
\hline$\varsigma 2$ & $L$ & $\tau$ & $9 T$ & 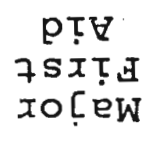 & \multirow{2}{*}{ 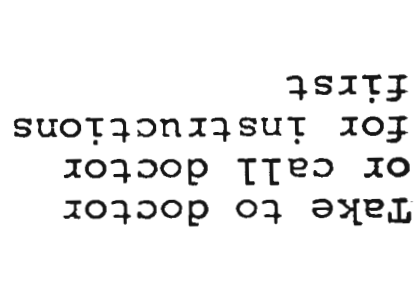 } \\
\hline 0 & 0 & 0 & 0 & 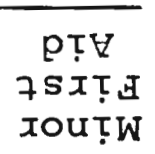 & \\
\hline 28 & $0 z$ & $8 T$ & $\nabla \nabla$ & 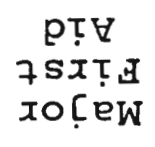 & \multirow{2}{*}{ 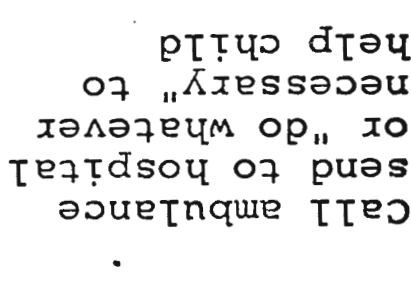 } \\
\hline 0 & 0 & 0 & 0 & 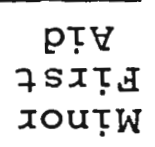 & \\
\hline $9 L$ & $\nabla \tau$ & $\varepsilon 乙$ & $6 \varepsilon$ & 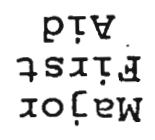 & \multirow{2}{*}{ 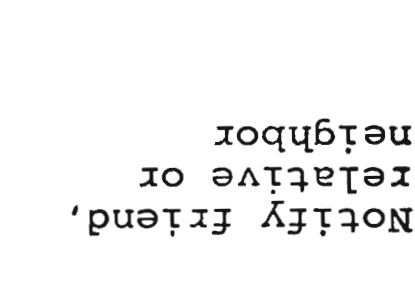 } \\
\hline $9 T$ & 2 & $\nabla$ & $0 \tau$ & 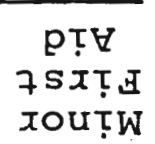 & \\
\hline $9 \tau T$ & $\varepsilon \varepsilon$ & $\tau \varepsilon$ & ZS & 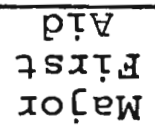 & \multirow[b]{2}{*}{ 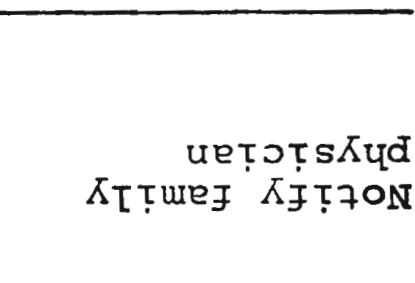 } \\
\hline $2 \tau$ & 2 & $L$ & $\varepsilon$ & 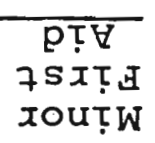 & \\
\hline 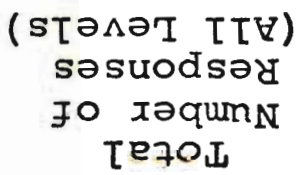 & $\begin{array}{l}\cdot \mathrm{S} \cdot \mathrm{H} \\
\text { (səsu }\end{array}$ & 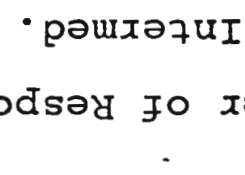 & $\begin{array}{l}\text { - uəT马 } \\
\text { qunn } N) *\end{array}$ & & \\
\hline
\end{tabular}

suoţenzts pț 7sxţ xo!̣ew pue xouț iof saxnpəsoxd tooyos uo s7uouruos, s7uaxed

†S GTGUL 
- uoțรanb әч7 07 səsuodsəx

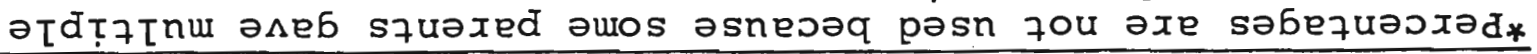

\begin{tabular}{|c|c|c|c|}
\hline$\varepsilon$ & $\tau$ & $s$ & ХәЧҰ० \\
\hline 0 & 0 & $\tau$ & ' uoțţppe әблет e әмеч 7,uptnous \\
\hline 2 & $\tau$ & 0 & 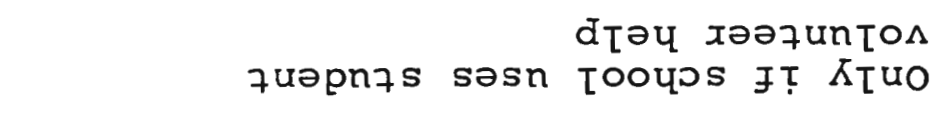 \\
\hline$\tau$ & $\varepsilon$ & 0 & 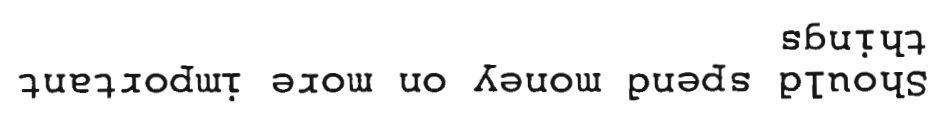 \\
\hline 2 & $\tau$ & 2 & 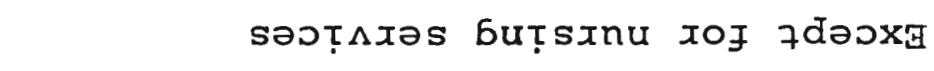 \\
\hline$\tau$ & 0 & 2 & pəppe səدт̣ıxəs uo spuədəđ \\
\hline $\begin{array}{r}\cdot S \cdot H \\
\text { (səs }\end{array}$ & $\begin{array}{l}\text { - рәитә7иI } \\
\text { dsәу э० }\end{array}$ & 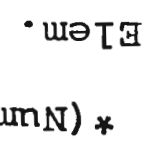 & \\
\hline
\end{tabular}

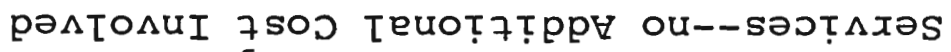

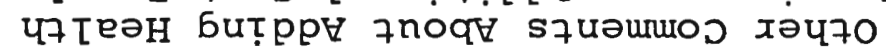

SS स्रTRU 
- Uотฺ75әnБ́ әЧ7 07 səsuodsəx

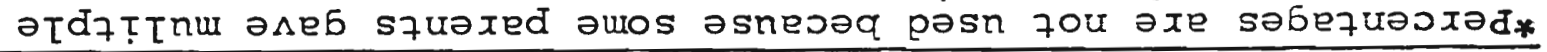

\begin{tabular}{|c|c|c|c|}
\hline$L$ & $\bar{D}$ & 9 & xəЧ70 \\
\hline 0 & 0 & $z$ & 7e suoțfezțunururt apțoxd ptnous \\
\hline$\tau$ & 0 & $\tau$ & səpțe y7теәч әxтT pInom \\
\hline$\tau$ & 0 & $\tau$ & sxәКеdxez Kq uo pə7ол әq pтnous \\
\hline$\tau$ & 0 & $\tau$ & səxe7 әsт̣ex 7.usəop 7? 于I \\
\hline 0 & 0 & $\tau$ & 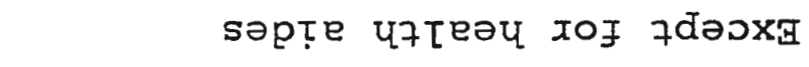 \\
\hline$\tau$ & 0 & 2 & səsxnu xof 7dә0x' \\
\hline$\tau$ & 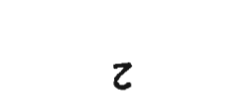 & 2 & 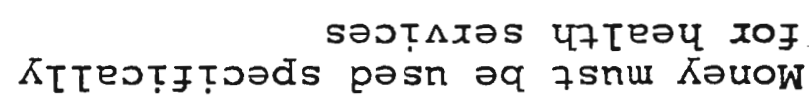 \\
\hline$\tau$ & $\varepsilon$ & 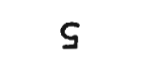 & 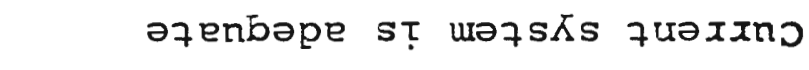 \\
\hline 6 & $\varepsilon$ & $L T$ & 7500 uo spurdad \\
\hline $\begin{array}{r}S \cdot H \\
\text { (səs }\end{array}$ & $\begin{array}{l}\text { - pәurлә7uI } \\
\text { dsəy fo } x\end{array}$ & $\begin{array}{l}\text { • urə Tت } \\
m N) *\end{array}$ & \\
\hline
\end{tabular}

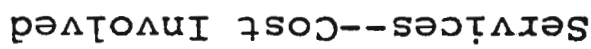

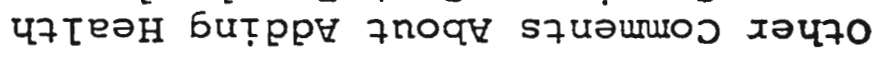

95 매TEH 


\begin{tabular}{|c|c|c|c|}
\hline$\tau$ & 0 & $\varepsilon$ & 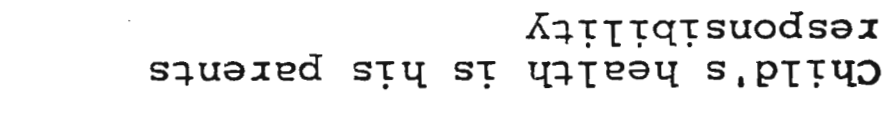 \\
\hline$\zeta$ & $\varepsilon$ & $\tau$ & 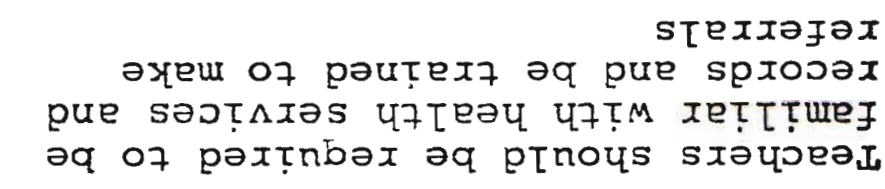 \\
\hline$\tau$ & $\forall$ & $\tau$ & 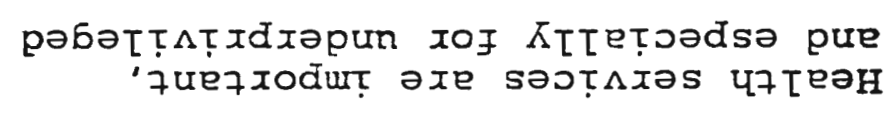 \\
\hline$\varepsilon$ & 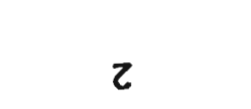 & $\varepsilon$ & $\begin{array}{l}\text { 7uezzodurt sț buțuəəxos } \\
\text { uoțsta pue buțeəu tenuut }\end{array}$ \\
\hline 0 & $\varepsilon$ & 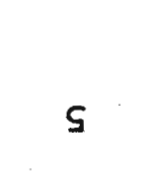 & 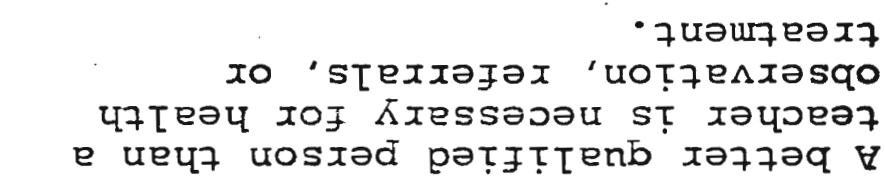 \\
\hline 乙 & $\varepsilon$ & $\nabla$ & 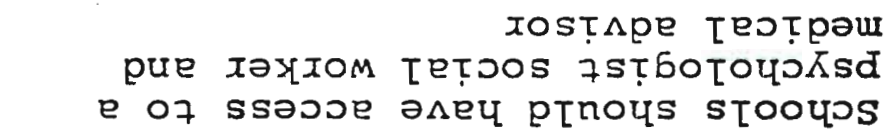 \\
\hline 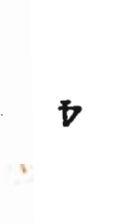 & 0 & 6 & 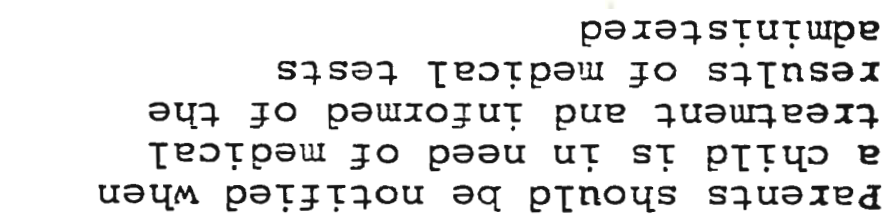 \\
\hline $\mathbf{S}$ & $\varsigma$ & 6 & 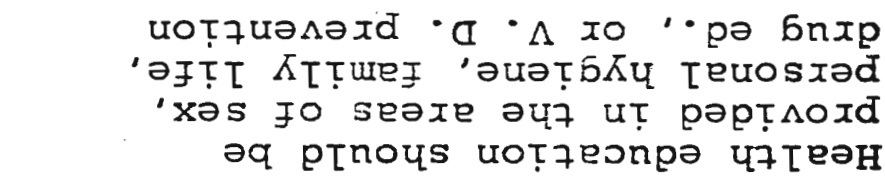 \\
\hline$\nabla \tau$ & $L \tau$ & 22 & 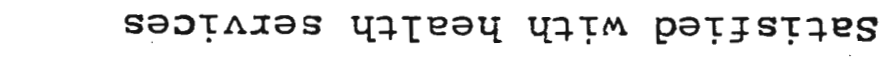 \\
\hline$\cdot S \cdot H$ & $\begin{array}{l}\text { pəuxтәнI } \\
\text { dsəy fo te }\end{array}$ & $\begin{array}{l}\text { - urəTa } \\
\mathrm{mN}) *\end{array}$ & \\
\hline
\end{tabular}

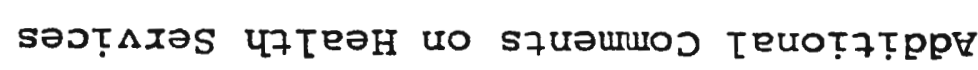

LS GTEU山 


\begin{tabular}{|c|c|c|c|}
\hline 29 & 99 & 96 & s[e70س \\
\hline$\$ 2$ & $8 T$ & $\tau \varepsilon$ & səsuodsəx エәЧ70 \\
\hline$\tau$ & 0 & $\varepsilon$ & ә7еnbəpeut әวuexnsuT Tooups \\
\hline 2 & 0 & $z$ & 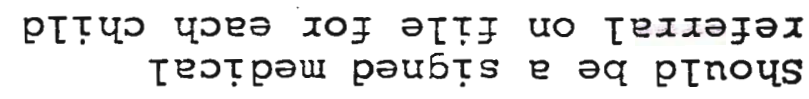 \\
\hline$\tau$ & $\mathbf{T}$ & 2 & 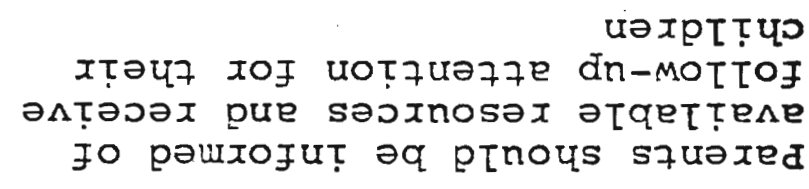 \\
\hline$\cdot S \cdot H$ & - pəurxəzuI & - uə TA & \\
\hline
\end{tabular}

( səsuodsəy fo xәqumN) * 